Aroueología Y SociedAd

№ 28, 2014: 71-114

ISSN: 0254-8062

RECIBIDO: MARZO DE 2014

ACEPTADO: SETIEMBRE DE 2014

\title{
ASENTAMIENTOS CHACHAPOYA EN EL NORTE DE LA PROVINCIA DE LUYA, DEPARTAMENTO DE AMAZONAS
}

\author{
DR. KLAUS KOSCHMIEDER \\ UNIVERSIDAD LIBRE DE BERLIN, ALEMANIA \\ rockydog@web.de
}

\section{RESUMEN}

La cultura arqueológica Chachapoya se desarrolló entre 800 y 1470 d.C. en la sierra nororiental del Perú. En la provincia de Luya, como en casi todo el territorio Chachapoya, los asentamientos residenciales (llaqtas) se ubican en las cumbres de los cerros (p. ej. Chichita) y con menos frecuencia en la base de los acantilados. Otros sitios, levantados en las laderas de las montañas, fueron habitados temporalmente, sobre todo durante las actividades agrícolas (p. ej. Pullía) o ceremoniales (p. ej. Kacta).

A primera vista los rasgos arquitectónicos parecen ser uniformes, ya que predominan edificios pétreos de planta circular u ovalada, originalmente cubiertos con techos cónicos de maderos y paja. No obstante, nuevos estudios demuestran particularidades, especialmente en la organización del espacio interior de los edificios y en la decoración de los muros exteriores con frisos geométricos y figurativos. Atribuimos estos rasgos distintivos a la presencia de diferentes grupos Chachapoya y a las diversas actividades que se desarrollaron en los ambientes circulares de las llaqtas.

Los resultados, obtenidos del presente estudio, tienen consecuencias para la interpretación de la función del complejo Kuelap, que no fue una fortaleza ni un típico centro poblacional, sino el centro administrativo y ceremonial más importante en el territorio norte de los Chachapoya.

PALABRAS ClAVE: Chachapoya, asentamientos residenciales, llaqtas, estructuras circulares, frisos, Kuelap, centro administrativo y ceremonial.

\section{ABSTRACT}

The archaeological culture known as the Chachapoya developed between 800 and 1470 AD in the northeastern highlands of Perú. In the province of Luya, as in most of the Chachapoya territory, residential settlements (llaqtas) are located on hilltops (Chichita) and less often at the base of cliffs. Other sites, located on the slopes of mountains, were occupied temporarily, mainly for agricultural activities (Pullía) or ceremonial matters (Kacta).

At first glance, the architectural features appear to be uniform, with a predominance of circular or oval stone buildings originally covered with conical roofs made of timber and straw. However, new studies show peculiarities in the configuration of the interior space of the buildings and the decoration of the exterior walls with geometric or figurative friezes. We attribute these distinctive features to the presence of different Chachapoya groups and to the diversity of activities that took place in the circular environs of the llaqtas. 
The results of the present study have significant implications for the interpretation of the function of the Kuelap complex, which was not a fortress nor a typical population center. Rather it was the most important administrative and ceremonial center in the northern territory of the Chachapoya.

Keywords: Chachapoya, residential settlements, llaqtas, circular structures, friezes, Kuelap, administrative and ceremonial center.

\section{INTRODUCCIÓN}

La distribución geográfica de los numerosos asentamientos con estructuras circulares u ovaladas (llaqta) define el antiguo territorio de la «cultura arqueológica» Chachapoya (Fig. 1). Varios investigadores, entre arqueólogos, historiadores y también aficionados, han recorrido la tierra de los antiguos chachapoya para «descubrir» y registrar los sitios arqueológicos de carácter residencial, administrativo, funerario y ceremonial. Los reconocimientos o prospecciones fueron realizadas al azar o en forma sistemática. Debemos resaltar los trabajos de L. Langlois (1939), Reichlen/Reichlen (1950), G. Savoy (1970), D. Thompson (1974, 1976), V. Zubiate (1984), M . Davis (1985, 1996), P. Lerche (1986), Lennon et al. (1989), K. Muscutt (1998), Kauffmann/Ligabue (2003), I. Schjellerup (2003, 2005 a y b, 2008), Bueno et al. (2006) y del autor (Koschmieder 2012). Otros investigadores se dedicaron a estudiar un solo sitio, lo que incluyó el mapeo, la descripción de los rasgos arquitectónicos, y de vez en cuando, la ejecución de excavaciones arqueológicas. De mucha importancia fueron los trabajos en la «ciudad fortificada» de Kuelap (Narváez 1988, 1996 a y b), en Vira Vira (Muscutt et al. 1993) y en el Abiseo, también llamado Gran Pajatén (Bonavía 1968; Lennon et al. 1989).

Las investigaciones arqueológicos en Kuelap tienen una larga tradición. Los primeros mapas fueron elaborados por los suizos A. Werthemann (1892) y A. Bandelier (1907, 1940) a fines del siglo diécinueve. El mismo Werthemann fue el primero en realizar excavaciones, pero según su propia declaración sus «apuntes sobre Cuelap se perdieron [...]» (Werthemann 1892: 149). Otros mapas del sitio fueron presentados por L. Langlois (1939: 31), H. Horkheimer (1958: Fig. 2) y A. Narváez (1988: 119). El de Narváez es el más detallado. Muestra el muro perimetral exterior, los tres accesos, las dos plataformas principales (Pueblo Bajo y Pueblo Alto), la ubicación de las más de 420 estructuras circulares así como las construcciones más imponentes, que son el «Tintero» y el «Torreón». El trabajo de Narváez (1988, 1996 a y b) representa la más minuciosa descripción de los rasgos arquitectónicos de Kuelap, pero lamentablemente los resultados de sus excavaciones arqueológicas, realizadas durante los últimos años en el interior de un sinnúmero de edificios circulares y en el «Tintero», no fueron publicados hasta la fecha. ${ }^{1}$ La presentación de los datos sería de suma importancia para poder entender esta obra monumental, la cuál fue denominada «lugar de refugio» (Middendorf 1974 [1895], III: 171), «ciudad fortificada» (Narváez 1988), «ciudad funeraria» (Langlois 1934: 28), «asentamiento urbano» (v. Hagen 2002: 103) o «centro de administración y de culto» (Kaufmann/Ligabue 2003: 127).

La gran mayoría de los trabajos científicos realizados en asentamientos chachapoya, se restringieron a la descripción o documentación de los rasgos arquitectónicos visibles (ver p.ej. Kauffmann/ Ligabue 2003; Ruiz 2010). Las primeras excavaciones, ejecutadas en el interior de edificios circulares u ovaladas, se limitaron a pequeños cateos o trincheras para poder obtener una estratigrafía (perfiles) y recuperar cerámica diagnóstica (ver p. ej. Kuelap - Reichlen/Reichlen 1950: 230-231; Ruiz 2009 [1972]: 49-50; Abiseo - Bonavía 1968: 35-37). En algunos sitios del Abiseo (La Playa) y de la región Uchucmarca (Inticancha, Pirkapirka) las excavaciones restringidas revelaron fortuitamente la presencia de fogones, pisos empedrados, cámaras subterráneas (almacenes?) y otras construcciones de piedra (Lennon et al. 1989: 50; Thompson 1974: 121-122, 1976: 99-100), pero no ofrecieron un panorama com-

1 Tampoco existen publicaciones (detallados) de varios «proyectos de investigación arqueológica», realizados durante los últimos años en Purun Llacta, Yalape, La Congona, Llaqtacocha, Navar, Puyan y otros sitios más. 


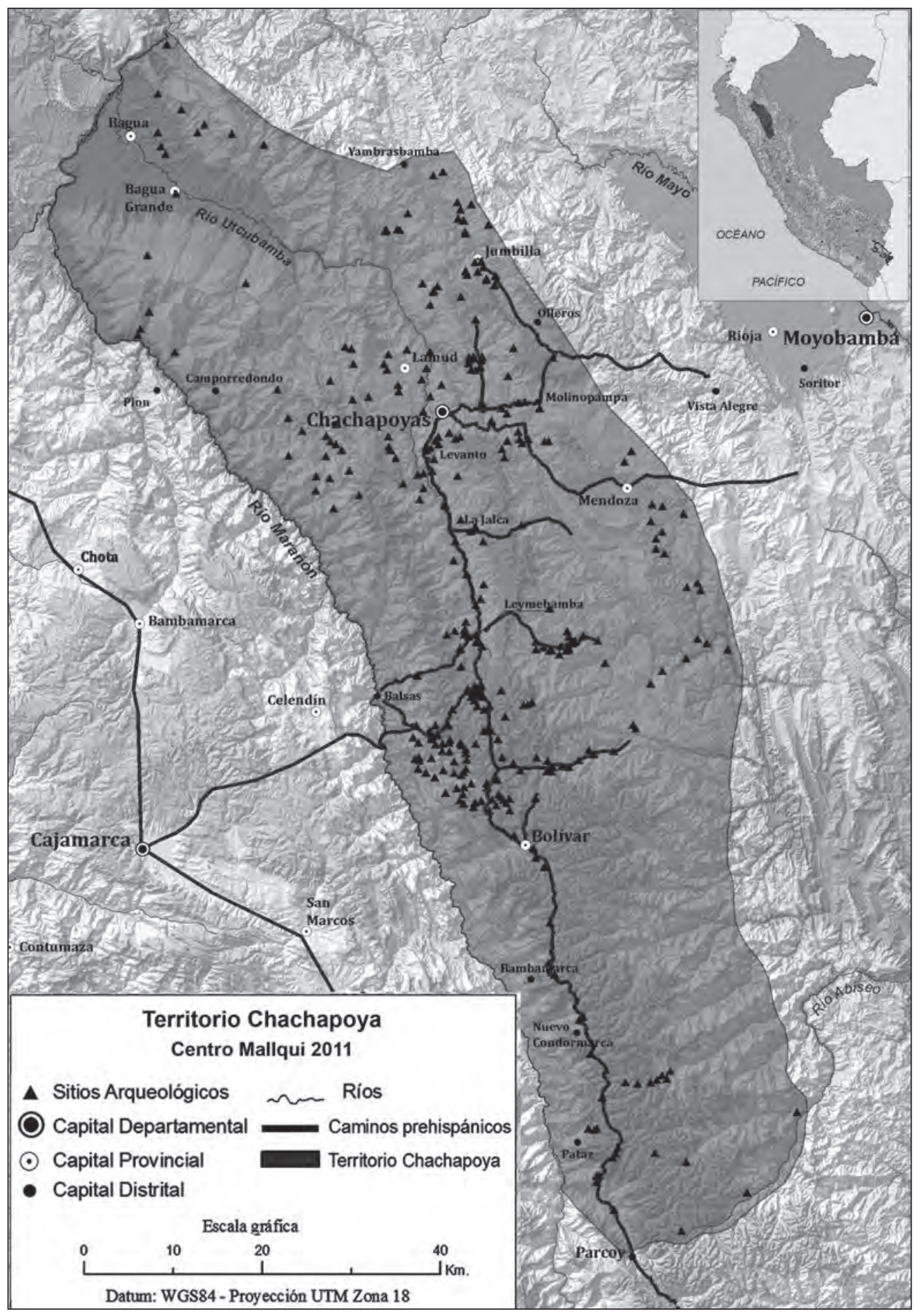

Figura 1. Mapa del territorio Chachapoya (Centro Mallqui 2011). 
pleto de los rasgos arquitectónicos de cada recinto investigado. Para poder entender las actividades, que se desarrollaron en el espacio interior de las estructuras circulares, es indispensable excavarlas por completo. ${ }^{2}$ Un espacio interior, excavado en área por el equipo de I. Schjellerup en Patrón Samana (Chuquibamba), reveló la presencia de tres cámaras subterráneas, un batán y un fogón asociado (Schjellerup 2005: 338-339). Durante los trabajos en Kuelap fueron descubiertas banquetas y canales (de drenaje). ${ }^{3}$ Casi todas las estructuras circulares presentan una o más cámaras subterráneas (Narváez 1996 b: 96), las cuales al parecer sirvieron como almacenes, algunos reutilizados como lugares de entierro. Otros rasgos arquitectónicos importantes fueron registrados por el autor en el transcurso del «Proyecto Arqueológico Jucusbamba» (Koschmieder 2012). ${ }^{4}$

El objetivo principal del presente trabajo es proporcionar nuevos datos acerca de la arquitectura chachapoya en la provincia de Luya, departamento de Amazonas. Los resultados de una prospección sistemática y de las excavaciones extensas, realizadas en sitios como Chichita, Juanitapampa, Kacta y Pullía, tienen también repercusiones para la interpretación del complejo Kuelap.

Las preguntas principales son:

¿Qué tipo de actividades se desarrollaron en el interior de los edificios circulares? ¿Fueron residencias como plantean la mayoría de los investigadores? ¿Fueron depósitos o almacenes como postúla el arqueólogo Kauffmann-Doig (Kauffmann/Ligabue 2003; Kauffmann 2009)? o ¿Fueron espacios públicos para fines ceremoniales y funerarios?

Para llegar a una conclusión tentativa hay que tomar en cuenta la ubicación geográfica de los asentamientos, el tamaño o diamétro de los edificios, los rasgos arquitectónicos en el espacio interior y los objetos muebles asociados.

Por primera vez se estudiaron también asentamientos con edificios semicirculares, los cuales se ubican en la base de los acantilados (Koschmieder 2012). Según Kauffmann Doig, sitios como Tingorbamba, también llamado Pueblo de los Muertos, exhiben «mausoleos» (Kauffmann/Ligabue 2003: 329-333) o "graneros» (Kauffmann 2009: 169-170), pero su equipo de trabajo no realizó excavaciones arqueológicas en este lugar. Nuestras investigaciones en Pueblo de los Muertos así como en Corralpampa, Amtia y Carnerocunga, dilucidan el asunto.

\section{LOS CHACHAPOYA}

Los chachapoya fueron migrantes que llegaron hacia un territorio extenso al este del río Marañon, donde eliminaron o desplazaron la escasa población autóctona. Su área de distribución, reconocido por sus restos arquitectónicos visibles, abarca una región entre las provincias de Bagua en el norte y Pataz en el sur, mientras el límite hacia el este, por falta de investigaciones, queda incierto (Fig. 1). Al momento de la llegada de los españoles una población de aproximadamente medio millón de habitantes ocupó esta área geográfica (Lerche 1995: 36).

Al parecer, el movimiento migratorio empezó a fines del Horizonte Medio (aprox. 800-1000 d.C.), pero no está claro de donde vinieron los diferentes grupos chachapoya. Algunos investigadores postularon un orígen serrano (p. ej. Bonavía 1998; Kauffmann/Ligabue 2003), otros piensan en una procedencia amazónica (p. ej. Koschmieder 2012). Lo cierto es que la tradición cultural Chachapoya no se desarrolló a nivel local o regional ${ }^{5}$, ya que sus restos arqueológicos, especialmente la arquitectura, no

2 Por lo que sabemos, solamente en Kuelap, en la región Chuquibamba (Schjellerup 2005) y en la cuenca del río Jucusbamba (Koschmieder 2012) se excavaron edificios circulares por completo.

3 Observación personal

4 Ver abajo

5 En base a los estudios en la zona del Abiseo algunos estudiosos postulan que la «cultura arqueológica» Chachapoya se formó a nivel local o regional (Church 1994; Church/v. Hagen 2008; v. Hagen 2002), pero no 
tienen antecedentes en el territorio ocupado. En la provincia de Luya, los asentamientos más antiguos ni siquiera muestran una arquitectura pétrea. Más bien, fueron construcciones simples de madera, barro y paja, llamado quincha (Koschmieder 2012: 36). La cerámica Chachapoya tampoco muestra una continuación o influencias de tipos anteriores. En el norte de la provincia de Luya las formas, la decoración y la pasta no coinciden con la cerámica precedente, denominada tipo Tosán (ibid.: 35-39). ${ }^{6}$

Los cronistas españoles, como Cieza de León, describieron a los chachapoya como «[...] los más blancos y agraciados de todos quantos yo he visto en las Indias [...]» (Cieza 1984 [1553], I: 229). Inspirado en estas declaraciones, no faltaron personas que afirman que los chachapoya fueron descendientes de los fenícios (Savoy 1996) o de los celtas (Giffhorn 2013), los cuales según sus fantasmagorias atravesaron el Atlántico y remontaron el río Amazonas hasta llegar a los Andes orientales del Perú. Pero es evidente que los chachapoya fueron de tronco andino, ya que tenían la misma estatura baja como sus vecinos, utilizaban símbolos andinos universales (Koschmieder 2012), enterraban su gente con los prestigiosos moluscos Spondylus y aprovecharon los mismos recursos naturales (p. ej. tubérculos, maíz, camélidos) como otros pueblos andinos para asegurar su subsistencia. Practicaban la caza de cabezas trofeo (Koschmieder/Gaither 2010; Murúa 2001 [1611]: 150; Salinas Loyola 1965 [1571], III: 197) y han sido famosos por sus brujos y curanderos, los cuales utilizaban plantas como el ishpingo (Acosta 1954 [1590]: 269; Arriaga 1920 [1621]: 26; Pizarro 1986 [1572]: 75; Polo de Ondegardo 1916 [1571], I: 30). Según la declaración de algunos cronistas adoraban a ciertos animales (culebras, cóndor) y a las estrellas (Calancha 1976 [1638], III: 836, 890; Garcilaso 1965 [1609], lib. VIII, cap. I: 291).

El orígen y el significado del término «chachapoya» es incierto, pero se supone que los inca dieron el nombre quechua a todos los autóctonos, reuniendo así los diferentes curacazgos en una sola unidad administrativa (Schjellerup 2005: 59). Según Lerche (1995: 27) «no podria ser una autodeterminación común de los diferentes grupos étnicos», ya que pertenecían a una o más familias lingüisticas diferentes. Desde el inicio del movimiento migratorio los grupos heterógenos se enfrentaban entre ellos. Un testimonio de los conflictos bélicos es la gran cantidad de restos óseos con fracturas y trepanaciones (cráneos) en los diferentes sitios funerarios. Probablemente se enfrentaban por la escasez de los recursos naturales y por la falta de tierras de cultivo, ya que la geografía se caracteriza por la presencia de quebradas profundas y acantilados altos. Los numerosos grupos étnicos, cuyos nombres originales en su gran mayoría se han perdido, se organizaron en curacazgos de variable complejidad y tamaño. Durante el tiempo de los Inca fueron encabezados por dos curacas, uno que se preocupaba de los asuntos administrativos y ceremoniales, y otro que dirigía las actividades bélicas (Lerche 1995: 38-42). Desconocemos si este orden dual existió antes de la llegada de los Inca. Los curacazgos actuaban en forma autónoma, pero en casos de una amenaza militar o para realizar trabajos colectivos varios subgrupos se unían (Espinoza 1967; Lerche 1995). Parece que fueron sociedades casí egalitarias, ya que hasta la fecha no se han identificado residencias y/o tumbas de élite. La forma de enterrar a las personas en sarcófagos de apariencia antropomorfa (en el norte) o en chullpas (en el sur) fue un patrón común entre las poblaciones chachapoya (Koschmieder 2012; Koschmieder/Gaither 2010). ${ }^{7}$

La presencia de múltiples grupos o curacazgos se manifiesta en primer lugar en las diferentes prácticas funerarias registradas, en la producción de diferentes tipos de ceramica y en la decoración

existen testimonios que señalen un gradual desarrollo a partir de tiempos tempranos (Precerámico o Formativo) hasta la aparición de la tradición chachapoya, especialmente en lo que se refiere a la arquitectura, las prácticas funerarias y la cultura material.

6 El tipo Tosán, definido por el autor (Koschmieder 2012: 36), apareció por primera vez a fines del Horizonte Temprano (aproximadamente a partir de 350 a.C.) y fue producido hasta fines del Horizonte Medio (aproximadamente 800-1000 d.C.) cuando uno de los grupos chachapoya llegó a la actual zona de Lámud-Luya.

7 Investigaciones recientes demuestran que algunas personas de alta jerarquía (curacas y/o guerreros) fueron enterrados en abrigos rocosos y en sarcófagos de gran tamaño (Koschmieder 2012; Koschmieder/Gaither 2010), pero los estudios sobre este tema están en sus comienzos. 
de los edificios circulares con frisos geométricos distintos, como rombos en el norte y grecas escalonadas en el sur. Después de un proceso de asimilación, los grupos chachapoya compartían múltiples rasgos en la arquitectura y en la elaboración de sus objetos utilitarios, lo que deja suponer que hubo una fase de unificación político-cultural que culminó en la creación de confederaciones entre algunos de los grupos chachapoya. La realización de obras monumentales (como Kuelap) y la capacidad de formar alianzas entre poblaciones, que en otras ocasiones se enfrentaban entre ellos (Cieza 1987 [1553], III: 293), son indicios de que hubo una tendencia hacia una macrorganización social con rasgos estatales (Lerche 1995). Especialmente la construcción de Kuelap plantea varias preguntas: ¿Cómo han podido organizar la mano de obra para poder erigir este monumento gigantesco? ¿Existió una autoridad central? ¿Qué función principal cumplía Kuelap en el territorio norte de los chachapoya? Obviamente no ha sido una fortaleza, ya que faltan parapetos y el abastecimiento de agua no estaba asegurado. Además el tiempo que necesitaron los constructores para poder terminar la obra monumental hubiera excedido el momento de una amenaza inminente. Proponemos echar una mirada hacia el interior de los numerosos edificios circulares para llegar a una interpretación más fehaciente.

\section{LAS LLAQTAS CHACHAPOYA}

La gran mayoría de los centros de población (llaqtas), algunos fortificados (p. ej. Kuelap), se sitúan en las cumbres de las montañas. Caminos, en parte empedrados, conectaban los asentamientos con los campos de cultivo y con otros sitios, que se encuentran en las laderas de las montañas (Koschmieder 2012: 79; Ravines 1994: 521).

En el norte del territorio chachapoya las llaqtas se ubican en la parte alta de la zona ecológica quichua (2500-3200 m), mientras en el sur predominan en la jalca (3200-4000 m) (Koschmieder 2012; Lerche 1986; Ravines 1994: 520; Schjellerup 2005: 369; Thompson 1974, 1976). Estas alturas concuerdan con el emplazamiento de los campos agrícolas, donde se cultivaron preferentemente el maíz (zona ecológica quichua) y los tubérculos, como la papa (zona ecológica jalca). ${ }^{8}$ Las diferencias regionales se explican por la geografía de la región, ya que desde el norte hacia el sur, las montañas van creciendo hasta alturas de más de $4000 \mathrm{~m}$.

Los cronistas españoles describieron el área geográfica como de difícil acceso, accidentada, húmeda y hostil:

«Montañas asperas donde siempre llueve [...] tierras montuosas, poblada de sabandijas, abundante de tigres, llena de árboles silvestres [...]» (Calancha 1976 [1638]: 866).

«[...] tierra muy áspera y de gran humedad, que todo el año no hace sin llover, y por esta causa los indios tienen sus casas edificadas en las cumbres de las cuestas y altos [...]» (Los primeros agustinos 1916 [1557]: 56).

Según Lerche (1995: 30), la opinión, que «los chachas edificaron sus ciudades en las laderas y cumbres de los cerros con fines estrictamente defensivos» (Espinoza 1967: 235), no corresponde a la realidad, ya que los sitios fortificados (como Kuelap) fueron excepcionales. En primer lugar la ubicación de los asentamientos chachapoya en las cumbres de las montañas se explica con la falta de otros terrenos adecuados para la construcción de un mayor número de edificios circulares. La geografía se caracteriza por la presencia de quebradas profundas y acantilados altos. Los valles fluviales son muy angostos para poder establecer asentamientos en su base. Es de suponer que los pocos sitios, conocidos en la playa del valle del río Utcubamba (Tuich, Macro, Condechaca), cumplían el rol de

8 Estudios recientes sobre la alimentación de los chachapoya sugieren que el consumo del maíz predominó en el norte del territorio chachapoya (Koschmieder 2012: 92-95), mientras en el sur la papa fue el alimento básico (Guengerich 2012: 236 ff.). 
controlar el tránsito y la producción del algodón (utcu), pero fueron sitios indefensos. Por otro lado, para la construcción de edificios en las laderas de las montañas se requerían mayores esfuerzos para nivelar el terreno y/o construir muros de contención. Además estos sitios se ubican en una posición estratégica desfavorable.

Otro argumento para explicar la construcción de las llaqtas en las alturas se basa en las condiciones climáticas. Las bajas temperaturas permitían el almacenamiento y la conservación de los productos agrícolas (Lerche 1986: 150; 1996: 42). Por algo, los sitios arqueológicos que muestran cámaras subterráneas (almacenes) en el espacio interior de sus recintos circulares, se ubican en alturas encima de los 3000 m (Schjellerup 2005; Thompson 1974, 1976).

Por lo general, los centros de población chachapoya carecen de espacios públicos. Las llaqtas presentan un conjunto de 30 a 400 edificios circulares que muestran un diámetro promedio de 4 a $8 \mathrm{~m}$, pero existen también sitios con más de 600 estructuras (p. ej. Olán) y recintos de mayor tamaño (p. ej. en Abiseo o en Kacta - D: 10-15 m) (Bonavía 1968: 13; Koschmieder 2012: 65; Lerche 1986: 146, 1995 : 29-31; Schjellerup 2005: 368-371; v. Hagen 2002: 91).

Los edificios pétreos descansan sobre terrazas artificiales o embasamentos semicirculares que presentan aleros o cornisas de lajas salientes, las cuales protegían la base de las estructuras de las lluvias (Koschmieder 2012; Narváez 1988, 1996 a y b; Schjellerup 2005). Por lo general los recintos no presentan ventanas y existe un solo acceso por el cuál la luz del dia iluminaba el espacio interior. Escalones conducen hacia el nivel de los pisos de las viviendas. El espacio interior de los recintos no fue subdividido en ambientes menores. ${ }^{9}$ En los muros interiores, originalmente enlucidos y posiblemente pintados, se observan nichos u hornacinas de diferente tamaño así como ganchos de madera, astas de venado y mandibulas de camélidos incrustados. Es de suponer que sirvieron para colgar utensilios de uso corriente.

Originalmente los edificios fueron cubiertos con techos cónicos de maderos y paja, como demuestran fotos y ilustraciones de estructuras todavía habitadas hasta el siglo XX (Langlois 1939; Werthemann 1892; Wiener 1884) (Fig. 2).

Algunos edificios están todavía adornados con frisos de piedra que representan motivos geométricos o figurativos (p. ej. Bonavía 1968; Lerche 1986, 1995, 1996; Narváez 1988, 1996 a y b; Schjellerup 2005). Están dispuestos horizontalmente y el motivo se repite con las mismas características. Se han identificado tres prototipos de los frisos geométricos. Mientras la distribución geográfica del zigzag abarca todo el territorio chachapoya, el rombo (norte) y la greca escalonada (sur) son ligadas a regiones distintas (Lerche 1995: 87; Schjellerup 2005: 70), indicando la presencia

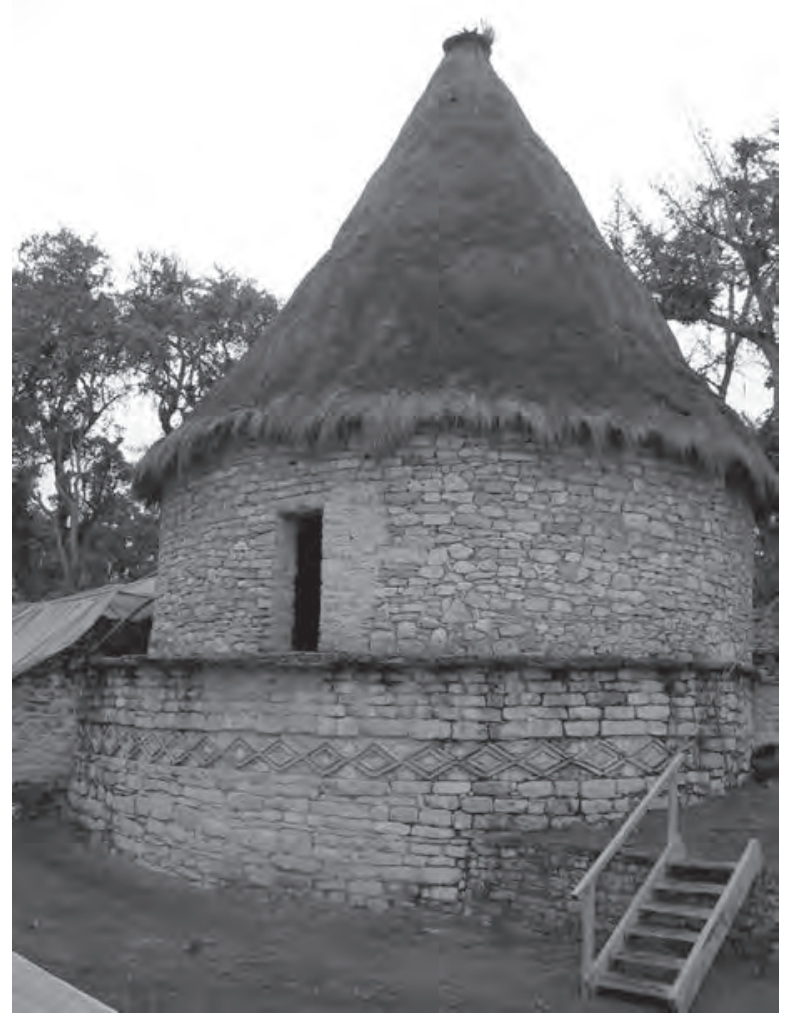

Figura 2. Reconstrucción de un edificio circular (Kuelap).

9 Sobre los rasgos arqueológicos, registrados en el espacio interior de los edificios, ver abajo. 
de diferentes macrogrupos chachapoya.$^{10}$ En el territorio sur se observan también cabezas clavas, incrustadas en los muros exteriores de algunos recintos (p. ej. Bonavía 1968: 93-94; Muscutt 1998: 40-41, 43-44; Savoy 1970: 141, 175; Schjellerup 2005: 340, 344).

\section{El Área de investigación (Proyecto Arqueológico Jucusbamba) y los PRIMEROS ESTUDIOS SOBRE ASENTAMIENTOS CHACHAPOYA EN ESTA REGIÓN}

Durante el Proyecto Arqueológico Jucusbamba (2006-2010) se realizaron trabajos de campo en un área de aproximadamente $40 \mathrm{~km}^{2}$, delimitada por el rio Utcubamba al oeste y el rio Jucusbamba al este (Fig. 3). El límite sur se estableció a la altura del pueblo de Lámud, capital de la provincia de Luya, departamento de Amazonas. Los sitios arqueológicos se ubican a alturas entre 1500 y $2700 \mathrm{msnm}^{11}$, así que los trabajos de campo se realizaron en terrenos horizontales (cumbres de las montañas) y verticales (acantilados y faldas de los cerros).

El objetivo principal del proyecto, dirigido por el autor, fue estudiar la prehistoria de una región con ocupación chachapoya mediante una prospección sistemática y excavaciones arqueológicas en asentamientos residenciales y sitios funerarios de diferentes épocas. Los sitios arqueológicos de la tradición chachapoya (aprox. 1000-1550 d.c.) predominan en este territorio. Entre otros abundan asentamientos con edificios circulares u ovaladas, campos de cultivo, caminos empedrados, sitios funerarios (p. ej. cuevas, abrigos rocosos, chullpas y sarcófagos de apariencia antropomorfa) y una gran cantidad de pinturas rupestres y petroglifos (Koschmieder 2012). En total se registraron 277 sitios arqueológicos, de los cuales solamente los asentamientos de Lámud Urco, Tosán y Amtia pertenecían a épocas anteriores a la ocu-

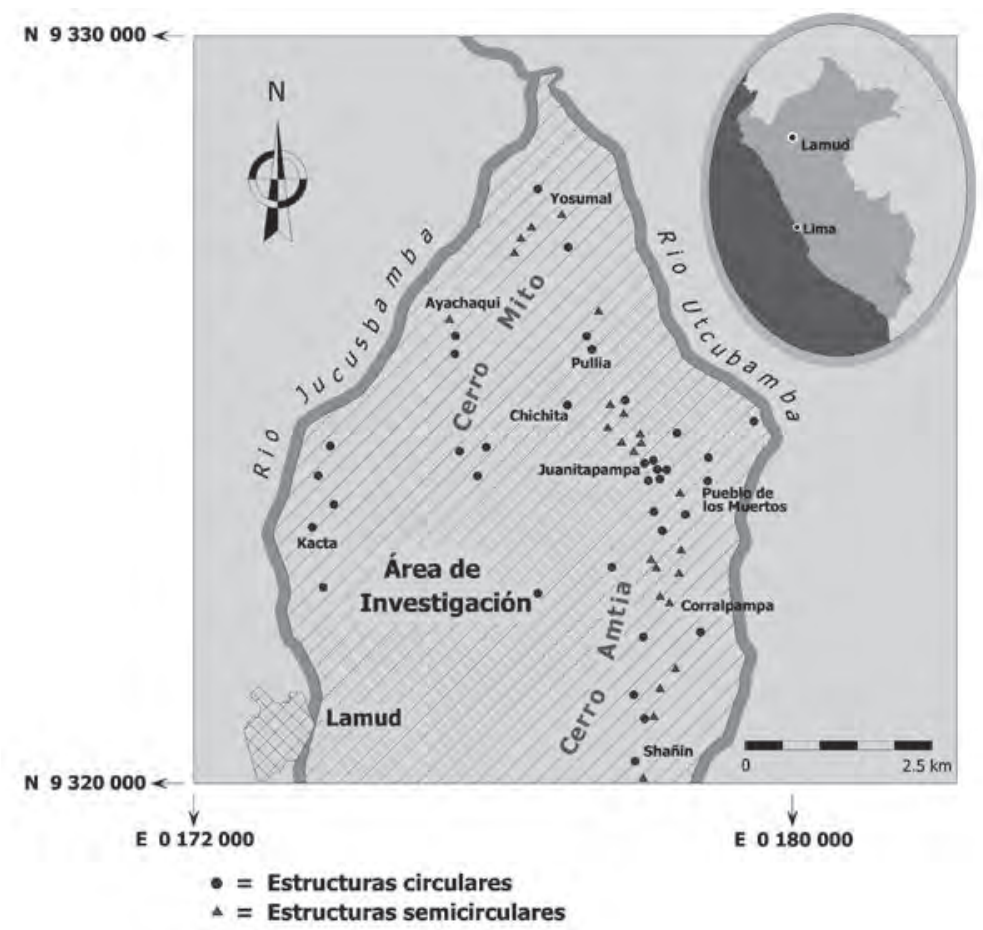

Figura 3. Zona de prospección y ubicación de los asentamientos Chachapoya (estructuras circulares y semicirculares).

10 Sobre la interpretación de los motivos véase Los Chachapoya y los símbolos de su historia de Peter Lerche (1995).

11 msnm = métros sobre el nivel del mar 
pación chachapoya. Lámud Urco es el único sitio que muestra una estratigrafía completa, que abarca el tiempo entre el Precerámico Tardío y el Horizonte Tardío (aprox. 2870 a.C. - 1500 d.c.) (ibid.: 35-40).

El único asentamiento chachapoya previamente estudiado en el área de investigación, ha sido Kacta (también llamado San Antonio), pero los investigadores no realizaron excavaciones arqueológicas en este lugar (Aguilar 1997: 23-26; Gil 1938: 132-137; Kauffmann 1989: 30-34; Kauffmann/Ligabue 2003: 439-444; Langlois 1934: 25-27; 1939: 52-59). Presentan planos muy esquemáticos y una descripción de los recintos circulares, los cuales se ubican encima de unas terrazas artificiales. Uno de los muros de contención todavía muestra un friso en forma de zigzag. ${ }^{12}$ Gil (1938: 134) hizo una reconstrucción hipotética de los edificios, pero es poco probable que hayan tenido techos en forma de bóveda de piedra y barro, como sostenía el autor. En la pared interior de uno de los edificios circulares más grandes se encuentran los restos de una pintura mural. El equipo de Kauffmann Doig ejecutó calcos de la escena principal, pero en los dibujos de lápiz no se aprecian muchos detalles (Kauffmann/Ligabue 2003: 442-443). ${ }^{13}$ Los investigadores no dan sus opiniones sobre la posible función de los grandes recintos de Kacta. Solamente Aguilar (1997: 25) sostiene que habrían servido para «ceremonias rituales».

Dos docenas de asentamientos con edificios semicirculares se ubican en el área de investigación (Koschmieder 2012: 70-77), pero solo el sitio de Tingorbamba o Pueblo de los Muertos llamó la atención de varios exploradores (Aguilar 1997: 27-30; Kauffmann/Ligabue 2003: 329-333; Savoy 1970: 166-169). El plano esquemático que presentan Kauffmann/Ligabue (2003: 330-331) muestra los restos arquitectónicos de unas 20 estructuras semicirculares, levantadas sobre una estrecha repisa natural, la cuál se orienta en forma recta de sur a norte. ${ }^{14}$ El equipo de Kauffmann registró varios frisos en bajorrelieve, plasmados en los muros interiores de algunos de los recintos (Kauffmann/Ligabue 2003: 330-331). Representan serpientes estilizadas y una «cruz andina» (Koschmieder 2012: 76-77, 123, 139, 141). La serpiente de forma más natural decoró la parte exterior de una banqueta con nichos (Kauffmann/Ligabue 2003: 330; Koschmieder 2012:123). ${ }^{15}$ En una primera interpretación Kauffmann clasificó los edificios semicirculares como «recintos funerarios» o «mausoleos» (Kauffmann/Ligabue 2003: 329), pero en una publicación más reciente considera que «podrian haber sido también depósitos de alimentos» (Kauffmann 2009: 170). ${ }^{16}$

Para poder esclarecer la función que cumplían los edificios circulares y semicirculares de filiación chachapoya, es indispensable realizar excavaciones. Solamente con los resultados de la investigación arqueológica podemos sacar conclusiones valiosas sobre las actividades domésticas, administrativas o ceremoniales que tuvieron lugar en los edificios de diferente tamaño y acabado.

\section{ASENTAMIENTOS CON EDIFICIOS CIRCULARES U OVALADOS EN EL ÁREA DE INVESTIGACIÓN}

En el área de investigación, entre los ríos Utcubamba y Jucusbamba, se registraron 56 asentamientos con edificios circulares u ovaladas (Fig. 3), de los cuales 32 sitios se ubican en las cumbres de las montañas, a alturas que oscilan entre 2450 y $2700 \mathrm{msnm}$. La mayor cantidad de sitios se concentra en la meseta de Juanitapampa, encima de los barrancos de «Pueblo de los Muertos». Al parecer forman parte de un solo asentamiento de grandes dimensiones, pero por la explotación de los terrenos para la agricultura y la

12 Ver abajo.

13 Una reconstrucción parcial de la escena presentamos en el Cap. 4.2.

14 Según nuestros estudios, el barranco con la repisa geológica tiene una forma semicircular y la orientación del sitio es de suroeste a noreste (Koschmieder 2012: 75).

15 A causa de los graves daños, provocados por las visitas incontrolables, el friso está a punto de desaparecer.

16 Kauffmann no nos explica como ha llegado a estas conclusiones. No realizó excavaciones arqueológicas en este lugar. En la superficie se observan solamente batanes, manos de moles (manzuelas) y quemas (fogones). 
ganadería, quedan solamente algunos «barrios residenciales» (= PAJ 193-198). ${ }^{17}$ La deforestación masiva de las mesetas de Lámud y la nivelación de algunos terrenos provocó la destrucción de muchos edificios circulares. A veces, los restos arquitectónicos han desaparecido por completo (p. ej. Lámud Urco - PAJ 256; Tosán - PAJ 265). Quedan solamente batanes, morteros, cerámica fragmentada y material óseo en la superficie. En otros casos se encuentran solamente segmentos de los muros circulares. Hoy en dia los asentamientos en las cumbres de las montañas cubren áreas pequeñas de uno o dos hectáreas y muestran un promedio de 10 a 20 estructuras por sitio. Originalmente los asentamientos más importantes de la región deben haber tenido entre 80 y 300 edificios circulares cada uno (Chichita, Juanitapampa). Algunos están asociados con corrales para la cría de camélidos (llamas/alpacas). Por la explotación actual de las mesetas (agricultura, ganadería) y la reforestación de algunas zonas (con árboles de eucalipto), no se observan antiguos campos de cultivo en las mesetas.

En las laderas de las montañas, a alturas entre 2100 y $2450 \mathrm{msnm}$, se registraron otros 24 asentamientos con edificios circulares $u$ ovalados (Fig. 3). Por su monumentalidad (Kacta - PAJ 237) o por su ubicación en zonas inclinadas y apartadas de los pueblos modernos (p.ej. Pullía - PAJ 157-A), no sufrieron mayores daños. La gran mayoría de estos sitios están asociados con antiguas terrazas de cultivo (p.ej. Pullía - PAJ 157-B) y depósitos de forma circular (p.ej. Corralpampa - PAJ 93). Kacta (PAJ 237) es el sitio más grande en la zona de investigación. Sus 44 edificios registrados, que se extienden desde la orilla del río Jucusbamba hasta el borde de la meseta (2320-2520 msnm), se hallan en forma muy dispersa en un área de aproximadamente 35 hectáreas. Forman pequeños grupos de 2 a 6 estructuras, levantadas en fila encima de terrazas artificiales. Destacan edificios de grandes dimensiones (diámetro: 8-12 m) que aún presentan muros enlucidos de buen acabado. ${ }^{18}$

Los 10 fechados de radiocarbono disponibles para el área de investigación, demuestran que todos los asentamientos chachapoya (con edificios circulares y semicirculares) fueron ocupados entre 1000 d.C. y el tiempo colonial temprano (Fig. 4). ${ }^{19}$

\section{ASENTAMIENTOS EN LAS CUMBRES DE LAS MONTAÑAS}

En las cumbres de las montañas se identificaron 32 asentamientos chachapoya con edificios circulares u ovaladas (Fig. 3). Los sitios con una «mayor cantidad» de estructuras registradas, Chichita (18 estructuras - PAJ 250) y Juanitapampa (14 estrucutras - PAJ 196), fueron escogidos para realizar excavaciones arqueológicas.

\section{Chichita (PAJ 250)}

El sitio arqueológico Chichita (PAJ 250) se ubica encima de una cresta rocosa, a unos $5 \mathrm{~km}$ al noreste del pueblo de Lámud (Fig. 3) ${ }^{20}$ Cubre un área de aproximadamente dos hectáreas a una altura de 26182636 msnm. Los 18 edificios circulares o ligeramente ovalados fueron levantados sobre tres terrazas superpuestas (Fig. 5) ${ }^{21}$, cuyos muros de contención muestran una altura entre 1,5 y 3,5 m. El muro de la terraza superior todavía presenta un alero en su borde superior. No se observaron embasamentos altos y semicirculares como en Kuelap. Tampoco hay evidencias de frisos en los muros exteriores de

17 La abreviatura PAJ significa Proyecto Arqueológico Jucusbamba y los números correlativos corresponden a los sitios registrados sucesivamente durante el trabajo de prospección (2007-2009).

18 Ver abajo.

19 Los fechados coinciden con los de los sitios funerarios de la zona de investigación (1035-1660 d.C.) (Koschmieder 2012: 43). 
Klaus Koschmieder / Asentamientos chachapoya en el norte de la provincia de Luya...

\begin{tabular}{|c|c|c|c|c|c|c|}
\hline $\begin{array}{l}\text { Sitio } \\
\text { arqueológico }\end{array}$ & Muestra & Código & Material & $\begin{array}{l}\text { Contexto } \\
\text { arqueológico }\end{array}$ & $\begin{array}{l}\text { Fechados calibrados } \\
\text { ( } 95 \% \text { probabilidad) }\end{array}$ & Laboratorio \\
\hline $\begin{array}{l}\text { Chichita } \\
\text { (PAJ 250) }\end{array}$ & $\mathrm{H}-\mathrm{I}-2$ & Beta-229164 & Carbón & Relleno (Casa 18) & 1520-1580 d.c. & $\begin{array}{l}\text { Beta Analytic, } \\
\text { Miami, USA }\end{array}$ \\
\hline $\begin{array}{l}\text { Chichita } \\
\text { (PAJ 250) }\end{array}$ & H-II-12 & Beta-229166 & Carbón & $\begin{array}{l}\text { Quema asociada al } \\
\text { entierro } 1\end{array}$ & 1290-1420 d.c. & $\begin{array}{l}\text { Beta Analytic, } \\
\text { Miami, USA }\end{array}$ \\
\hline $\begin{array}{l}\text { Kacta } \\
\text { (PAJ 237) }\end{array}$ & I-K-II y III & GdC-504 & Madera & $\begin{array}{l}\text { Gancho incrustado } \\
\text { en el muro de la } \\
\text { Casa } 13\end{array}$ & 1275-1400 d.c. & $\begin{array}{l}\text { Gliwice, } \\
\text { Polonia }\end{array}$ \\
\hline $\begin{array}{l}\text { Kacta } \\
\text { (PAJ 237) }\end{array}$ & I-K-IV-a & GdC-547 & Carbón & Fogón (Casa 17) & 1406-1481 d.c. & $\begin{array}{l}\text { Gliwice, } \\
\text { Polonia }\end{array}$ \\
\hline $\begin{array}{l}\text { Kacta } \\
\text { (PAJ 237) }\end{array}$ & I-K-VI-a & GdS-1129 & Madera & $\begin{array}{l}\text { Gancho incrustado } \\
\text { en el muro de la } \\
\text { Casa } 32\end{array}$ & 1025-1255 d.c. & $\begin{array}{l}\text { Gliwice, } \\
\text { Polonia }\end{array}$ \\
\hline $\begin{array}{l}\text { Pueblo de los } \\
\text { Muertos } \\
\text { (PAJ 70) }\end{array}$ & I-PAJ 70-a & GdS-1134 & Madera & $\begin{array}{l}\text { Dintel de un nicho } \\
\text { - Recinto } 20\end{array}$ & 1285-1425 d.C. & $\begin{array}{l}\text { Gliwice, } \\
\text { Polonia }\end{array}$ \\
\hline PAJ 89 & I-PAJ 89 & GdC-522 & Carbón & $\begin{array}{l}\text { Debajo del muro } \\
\text { (Momento de } \\
\text { construcción) }\end{array}$ & 1035-1210 d.c. & $\begin{array}{l}\text { Gliwice, } \\
\text { Polonia }\end{array}$ \\
\hline $\begin{array}{l}\text { Pullía } \\
\text { (PAJ 157) }\end{array}$ & I-PAJ 157-C & GdC-537 & Carbón & Relleno (Casa 9) & 1465-1615 d.C. & $\begin{array}{l}\text { Gliwice, } \\
\text { Polonia }\end{array}$ \\
\hline $\begin{array}{l}\text { Carnerocunga } \\
\text { (PAJ 158) }\end{array}$ & I-PAJ 158-a & GdS-1185 & Carbón & Relleno (Recinto 2) & 1215-1400 d.c. & $\begin{array}{l}\text { Gliwice, } \\
\text { Polonia }\end{array}$ \\
\hline $\begin{array}{l}\text { Juanitapampa } \\
\text { (PAJ 196) }\end{array}$ & I-PAJ 196-b & GdS-1182 & Carbón & Relleno (Casa 13) & 1465-1710 d.c. & $\begin{array}{l}\text { Gliwice, } \\
\text { Polonia }\end{array}$ \\
\hline
\end{tabular}

Figura 4. Fechados disponibles para los asentamientos Chachapoya en la zona de Lámud-Luya (estructuras circulares y semicirculares).

los edificios, pero está situación tal vez se debe a la poca altura de los muros. En un solo caso (edificio 18) se registraron aleros, pero las lajas sobresalen solamente 10 a $20 \mathrm{~cm}$ de la fachada.

Los edificios de Chichita son muy uniformes. No resaltan construcciones extraordinarias o extrañas («tipo Tintero» - Kuelap) que podrian haber tenido una función ceremonial o administrativa. El diámetro de los edificios de Chichita varía entre 5,6 y 7,8 m. En su gran mayoría no son exactamente circulares, sino ovalados. Los muros se encuentran ligeramente inclinados hacia el interior y tienen un ancho de 0,35-0,55 m. A pesar de su mal estado de conservación, algunos mantienen una altura entre 2 y 5 m (Fig. 6). El material de construcción consiste en un $90 \%$ de piedras areniscas cuarzosas. Los $10 \%$ restantes se distribuyen entre calcarenitas, limonitas cuarzosas, limonitas calcáreas y calizas micríticas (Vásquez 2006). En algunos casos la mampostería, compuesta por piedras de diferente tamaño, fue levantada en tramos horizontales o en forma de espiral, algo que observó también Gil (1938: 133) en Chipuric: «las casas son circulares, cuyas bases ... ascienden en espiral.» Probablemente los constructores utilizaban una especie de encofrado para poder realizar los trabajos de construcción durante varias etapas. La mampostería está adherida por un mortero arcilloso de color marrón, el cuál contiene numerosos fragmentos de cerámica, objetos líticos quebrados (manos de moler, hachas) y una gran cantidad de restos orgánicos, como paja, moluscos, carbón y huesos de animal. Originalmente los muros fueron revestidos de un enlucido de arcilla blanca, pintada de colores rojo y amarillo. Todavía quedan algunos vestígios en la entrada del edificio 18 y en el paramento interior de los edificios 5 y 15. Se registraron huesos de camélidos y astas de venado incrustados en la mampostería 


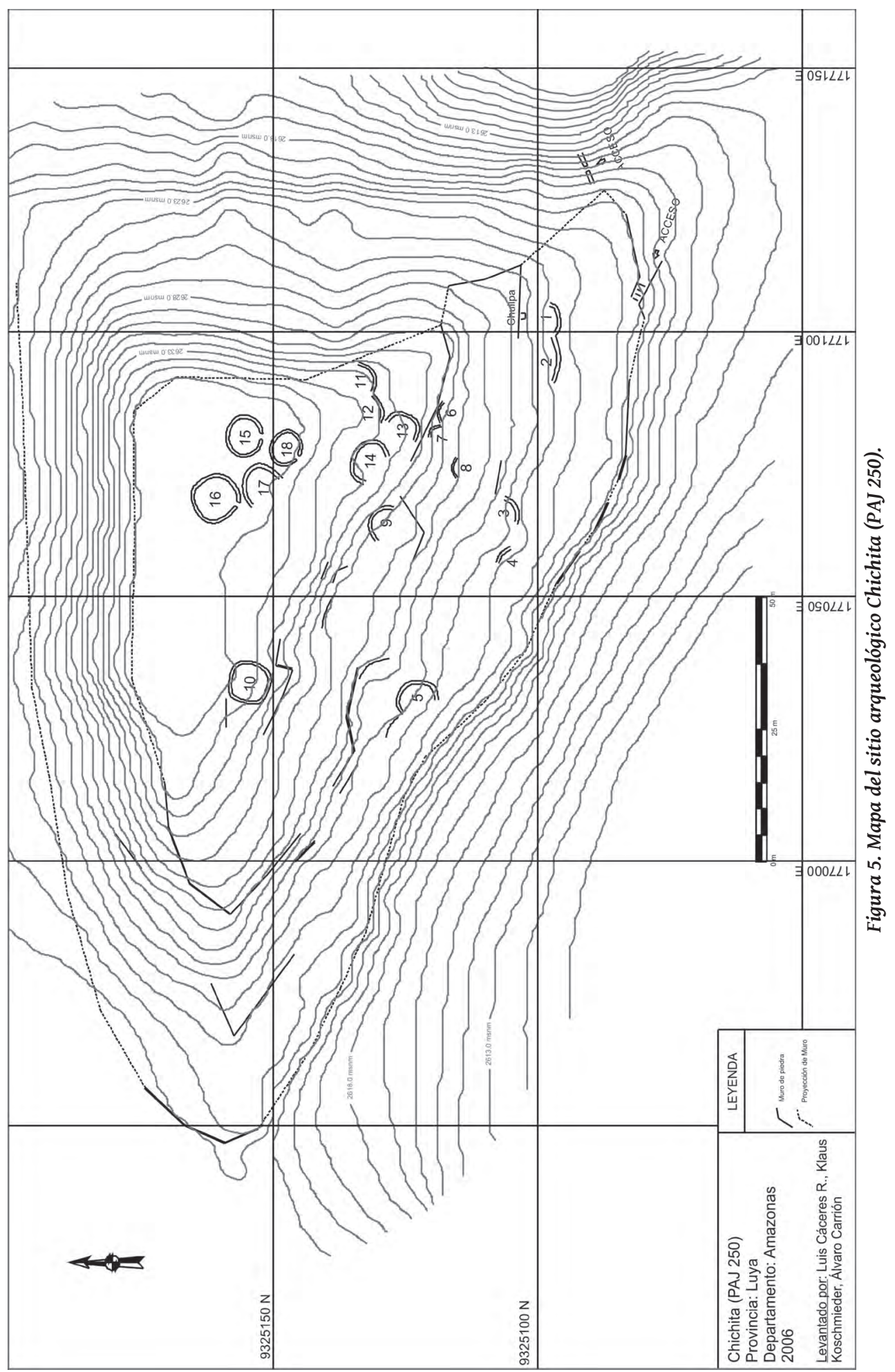




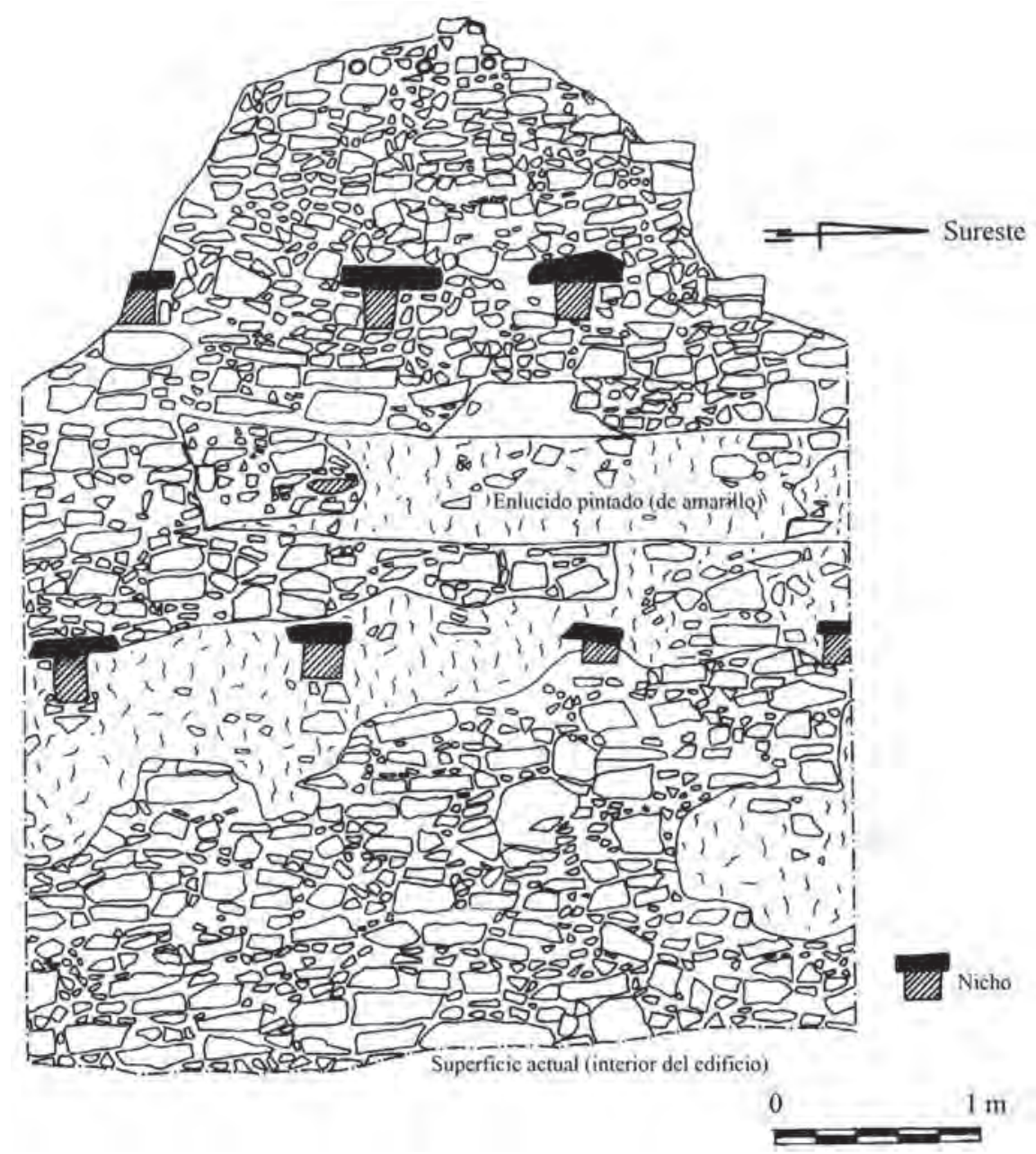

Figura 6. Mampostería con hornacinas en el edificio 5 de Chichita (PAJ 250).

de los edificios. Posiblemente sirvieron para colgar utensilios. En el paramento interior se observan también nichos de diferente tamaño que llevan un dintel de piedra. Los nichos más grandes muestran un ancho de 40-60 cm, una altura de $35-40 \mathrm{~cm}$ y una profundad de $30 \mathrm{~cm}$. Conservan un enlucido con restos de pintura roja. Otras hornacinas más pequeñas (machinales) se encuentran en filas horizontales y decoran el interior de los recintos (Fig. 6). También llevan dinteles de piedra.

Los vanos de acceso tienen un ancho de 0,95-1,20 m y muestran un umbral en forma de una sola laja de piedra calcarenita. Abarca todo el largo y ancho del acceso. Las lajas utilizadas tienen un largo de 1,0-1,1 $\mathrm{m}$, un ancho de 0,40-0,45 $\mathrm{m}$ y un espesor de 0,06-0,18 $\mathrm{m}$. No se han conservado los dinteles de las entradas, pero el acceso del edificio 18 muestra todavía una altura de 2,0 m (Koschmieder 2012: 69).

De los escombros del recinto 16 proviene una laja de piedra de forma circular, la cuál muestra un orifício en el medio (Fig. 7). ${ }^{22}$ Langlois (1939: 65), quién visitó un edificio circular todavía habitada en el año 1933 en La Jalca, observó que el techo cónico de paja «...está recubierto de una gran loza que

22 El arqueólogo A. Ruiz Estrada reporta otra «rueda de piedra» en Kuelap (Ruiz 2010: 35, Fig. 7). 


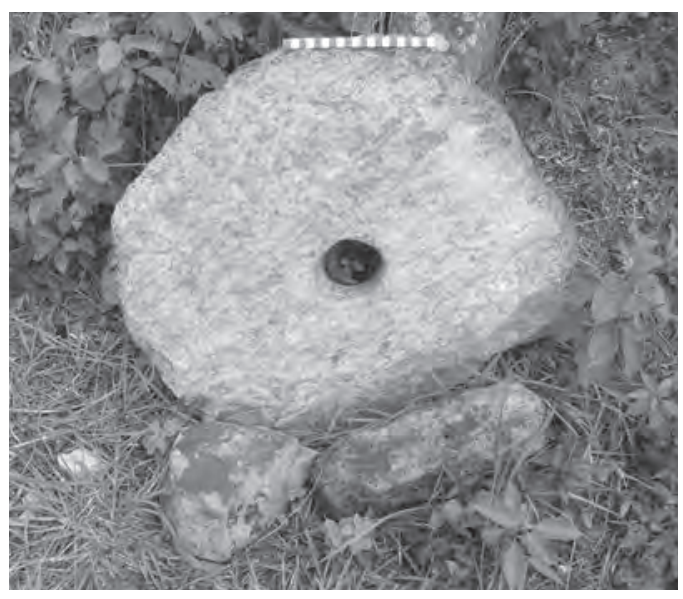

Figura 7. Laja de piedra de forma circular (Chichita-PAJ 250).

da una fisonomia curiosa al conjunto.» Por su peso la piedra circular sirvió para proteger el extremo del techo de los fuertes vientos y de las lluvias. La punta del techo, pasando el orifício de la piedra, fue amarrada en forma de un haz. Una planta de agave coronaba la construcción y impedía a los pájaros de pararse sobre el techo.

Las excavaciones arqueológicas se realizaron en el espacio interior de tres edificios (No. 10, 15 y 18). Los recintos $10\left(56,2 \mathrm{~m}^{2}\right)$ y $18\left(32,5 \mathrm{~m}^{2}\right)$ fueron excavados por completo, mientras en la estructura 15 se excavó una trinchera de $2 \mathrm{~m}$ de ancho que atravesó todo el espacio interior desde el acceso hasta el muro opuesto.

En cada uno de los recintos se registraron un peldaño en forma semicircular, un batán, manos de moler (manzuelas) fragmentadas, quemas (ceniza), desechos orgánicos y una variable cantidad de entierros. Un caso típico representa el edificio 18 (Fig. 8). A unos 10-15 cm debajo del nivel superior del umbral se ubica un peldaño en forma semicircular. ${ }^{23}$ El espacio entre el muro de contención del peldaño y el umbral fue rellenado con numerosos fragmentos de cerámica, objetos líticos y huesos de camélidos, y finalmente cubierto con una capa de barro. Del peldaño se baja unos $10 \mathrm{~cm}$ para llegar al nivel del último piso (superficie apisonada). ${ }^{24} \mathrm{En}$ la parte trasera del recinto, mayormente al lado derecho, se ubica un batán de grandes dimensiones $(1,15 \times 1,05 \times 0,35 \mathrm{~m})^{25}$, rodeado por desechos orgánicos (semillas carbonizadas, huesos de animal [camélidos, cuyes, venados, perros y vizcachas] ${ }^{26}$ y caracoles terrestres), manos de moler con protuberancias circulares (manzuelas) y evidencias de quemas o fogones simples ${ }^{27}$. Todos los batanes de Chichita fueron elaborados de rocas calizas esparíticas y muestran una superficie plana (edificios 10 y 18) o ligeramente cóncava (edificio 15). Los abundantes restos orgánicos, encontrados en sus alrededores, dejan suponer que sirvieron para triturar granos y otros productos alimentícios.

En el espacio interior del edificio 10 se descubrió un reservorio de agua, adosado al batán (Fig. 9). Está compuesto por piedras grandes y medianas, unidas por una argamasa calcífera. Es una construcción de forma rectangular con un espacio interior de 1,0 x 0,8 m y con una profundidad máxima de 0,35 m. La base del reservorio corresponde al suelo geológico que es casi impermeable al agua. De su esquina oeste sale un canal de desagüe que se orienta hacia el sur para finalmente desaparecer debajo del muro del recinto. El canal tiene un ancho de 0,15-0,25 $\mathrm{m}$ y una altura de 0,22-0,30 $\mathrm{m}$. Está cubierto con lajas de piedra, de las cuales algunas alcanzan un tamaño de 0,6 x 0,5 m. Piedras colocadas de pie

23 El peldaño semicircular del edificio 15 es el más elaborado. Su muro de contención, levantado de 5 hileras de piedras medianas y pequeñas (unidas con una argamasa), tiene un ancho de 0,35-0,40 m y una altura máxima de $0,60-0,70 \mathrm{~m}$.

24 En el interior de todos los edificios investigados se detectó una superposición de apisonados. Parece que fueron renovados periódicamente.

25 Los batanes, encontrados en los otros dos recintos, tienen las siguientes dimensiones: 1,30 x 1,20 x 0,20 m (edificio 10) y $0,90 \times 0,85 \times 0,20$ (edificio 15 ).

26 Koschmieder 2012: 91

27 No se han identificado fogones, delimitados por piedras (para sostener las ollas?). Al parecer son típicos para el territorio sur de los chachapoya (Guengerich 2012; Schjellerup 2005). 


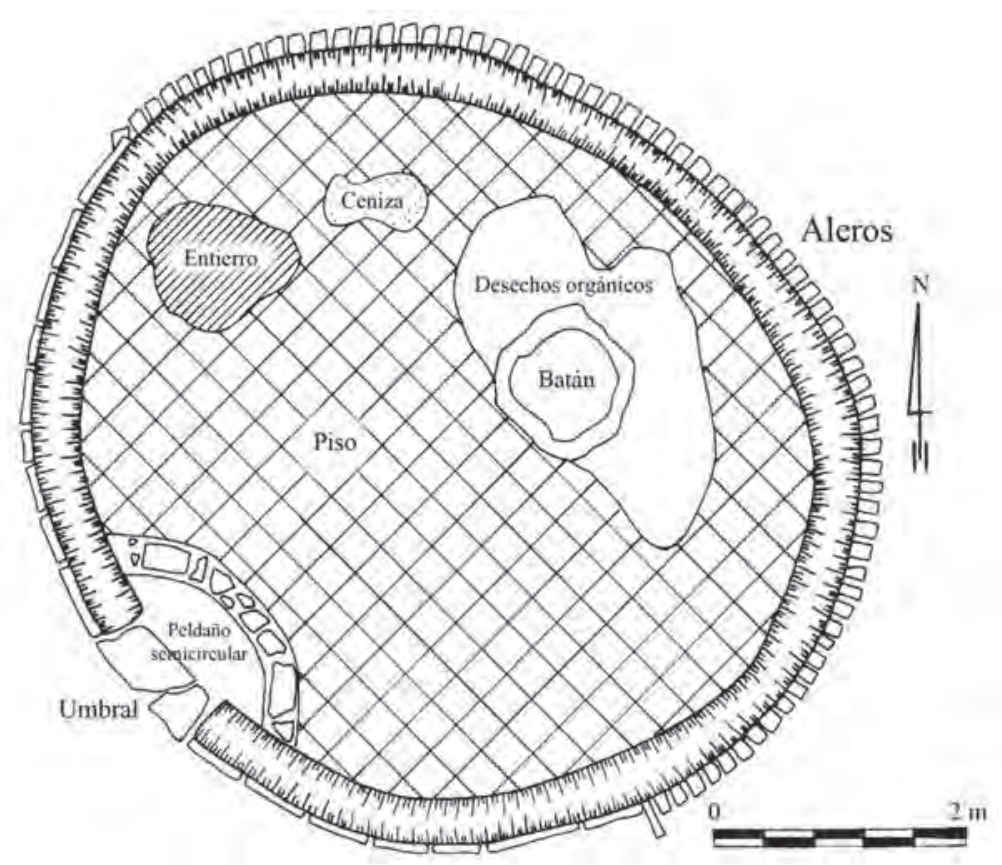

Figura 8. Espacio interior de un edificio circular (Edificio 18 - Chichita - PAJ 250).

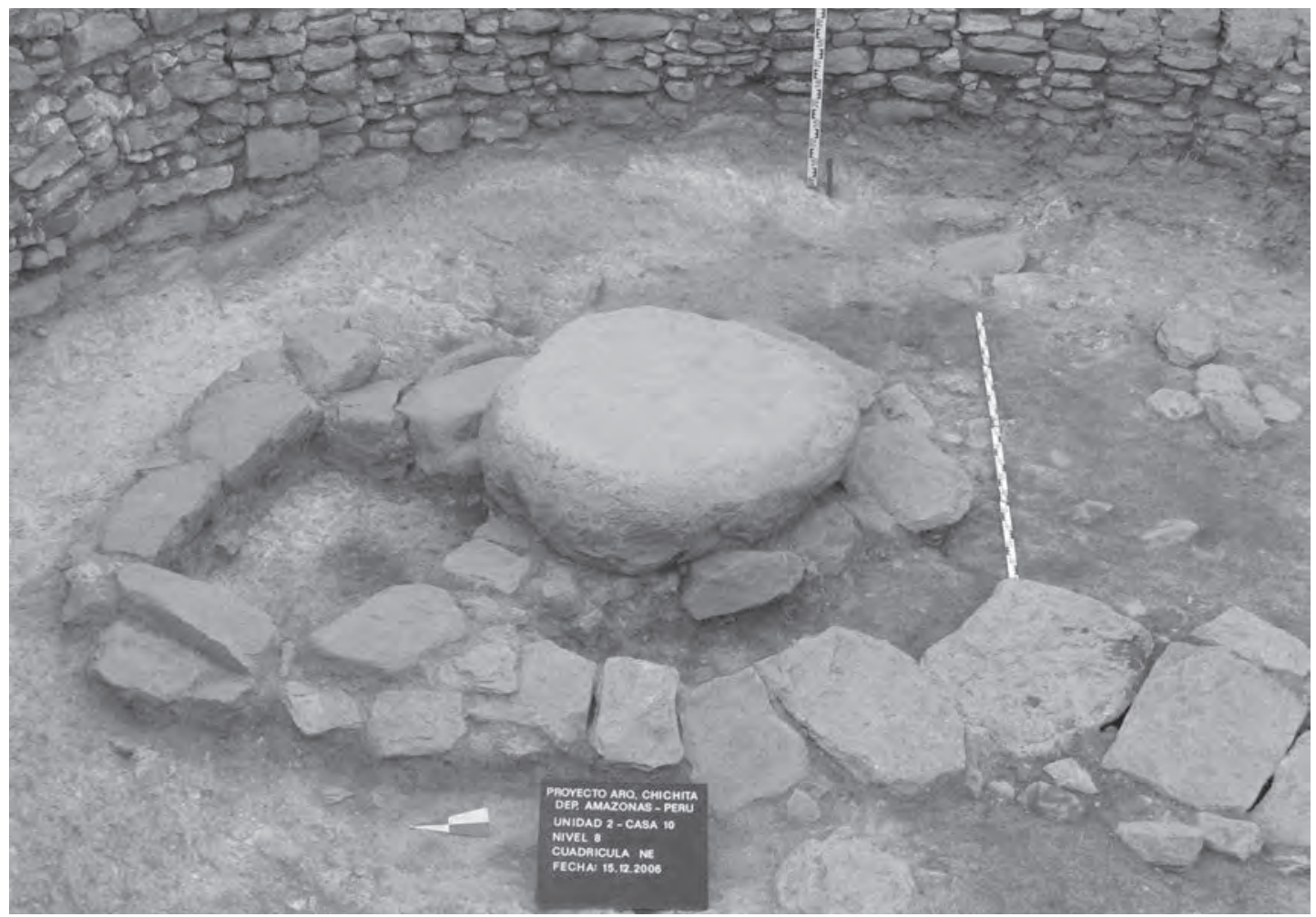

Figura 9. Batán, reservorio de agua y canal de desagüe en el interior del edificio 10 (Chichita-PAJ 250). 
sostienen las lajas. Desde el reservorio hasta el muro sur el canal muestra un declive de más de $50 \mathrm{~cm}$. Sobre la función del reservorio se puede especular, pero su cercanía al batán y unas quemas dejan suponer que algo tenía que ver con la preparación de la comida y otras actividades domésticas. Para llenar el depósito con agua los habitantes del edificio tenían que traer el líquido (en cántaros grandes), mientras el desagüe funcionó por medio del canal.

En el espacio interior de todos los edificios investigados se hallaron tumbas. Los entierros fueron depositados durante la ocupación de los ambientes, ya que por encima de las fosas se renovaron los pisos. Es de suponer que los muertos fueron parientes de los que todavía utilizaban los ambientes como vivienda.

En total se registraron nueve entierros, de los cuales siete se distribuían en la parte sur del edificio 10, mientras los dos restantes se registraron en los edificios 15 y 18 . Todos los esqueletos se encontraron en una posición fetal, típica para las formas de enterramiento en el territorio chachapoya. Llama la atención que no existió una regla como depositar a los muertos. La posición de los esqueletos y su orientación son muy individuales. En el caso de Chichita los fallecidos fueron colocados en una posición decúbito ventral, dorsal o lateral, y se identificó también un individuo sentado. Mientras las fosas en los edificios 15 y 18 fueron cavadas en el suelo geológico, los entierros del edificio 10 se registraron dentro de un relleno grueso que sirvió para nivelar el terreno inclinado. Varios entierros del edificio 10 han sido alterados ó disturbados por la remodelación constante del espacio interior. Otros dos individuos se encontraron debajo de un muro, de tal manera que algunos huesos fueron aplastados por el peso de las piedras (Koschmieder/Paredes 2007: 10).

La única tumba del edificio 18 se encontró en una fosa ovalada (Fig. 10), cavada en el suelo geológico y clausurada por el piso encima. La fosa estuvo delimitada por unas piedras y asociada con quemas cercanas. Probablemente fueron los residuos de un ritual, realizado durante el funeral. El

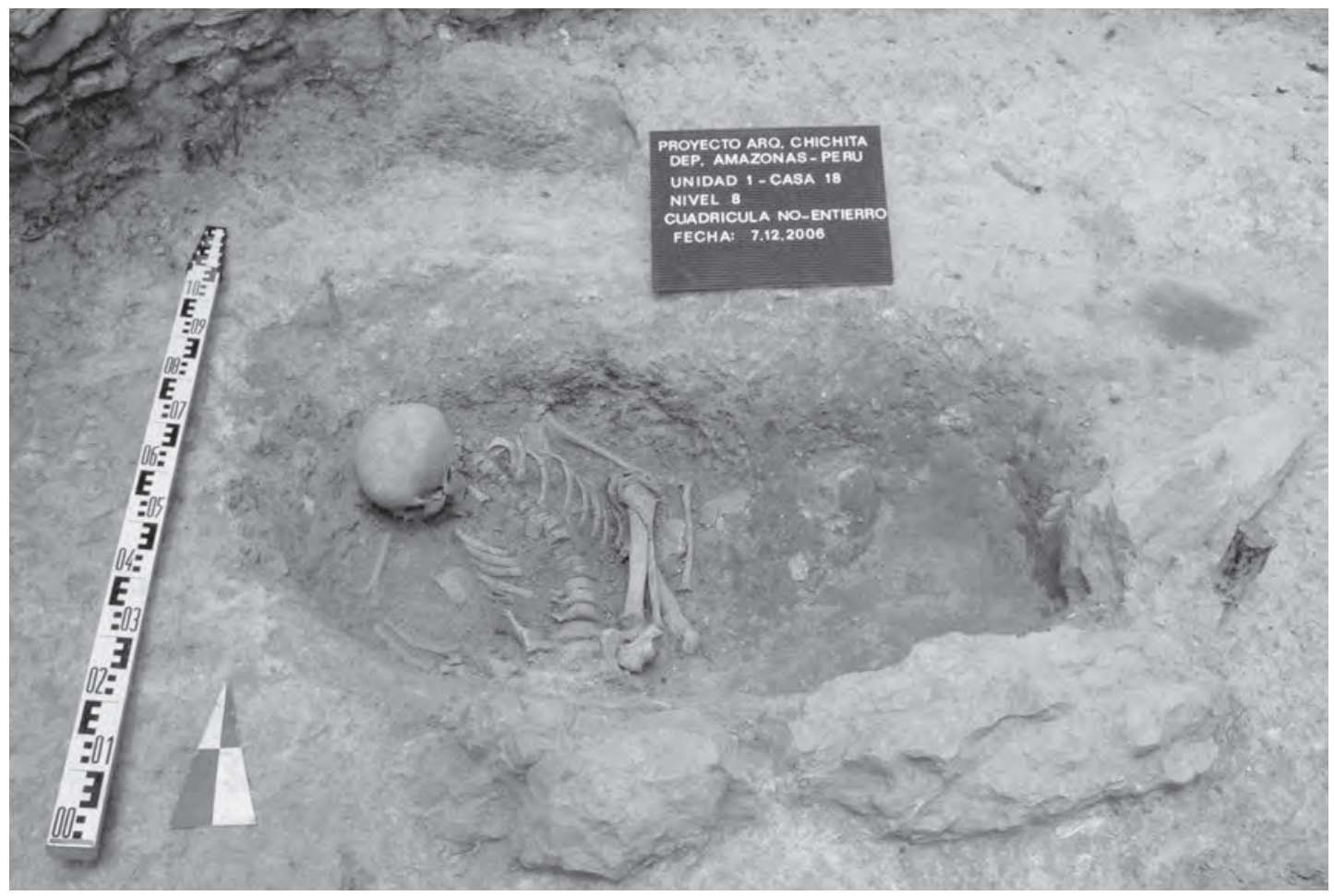

Figura 10. Entierro simple en el interior de una vivienda circular (Edificio 18 - Chichita-PAJ 250). 
esqueleto se encontró en una posición decúbito dorsal. Le acompañaron una hacha de piedra y un proyectil para hondas. Otras ofrendas simples, asociadas a los entierros de Chichita, fueron objetos líticos así como huesos y moluscos marinos trabajados (agujas, espátulas, punzones, tubos, cuentas de collar y placas recortadas). Destaca la presencia de una flauta fragmentada, elaborada de un hueso de cóndor (Entierro 6 - Edificio 10). Las ofrendas simples se distribuían alrededor o encima del lugar del entierro. No se registraron ceramios, metales o textiles asociados a los entierros. ${ }^{28}$

Los esqueletos, analizados por la antropóloga Catherine Gaither (2007), pertencían a 6 adultos (25-60 años), una joven (12-15 años) y dos niños (3-4 años). Entre los adultos Gaither identificó cinco mujeres y dos hombres. La estatura promedia era de $149-159 \mathrm{~cm}$, pero se registró también el esqueleto de un hombre con una estatura de $169 \mathrm{~cm}$ (entierro 6 - edificio 10), el cuál sufrió de una enfermedad del sistema endocrino, llamada acromegalia (Gaither et al. 2008). Consecuentemente los restos óseos del individuo demostraron osteoporosis severa y extensa. En el mismo edificio se halló el esqueleto de una mujer (45-60 años), probablemente decapitada (entierro 1 - edificio 10). Una porra estrellada de piedra fue depositada a la altura del cráneo faltante, talvez para recordar en que forma murió la mujer. Los resultados de Chichita demuestran una vez más la costumbre de los grupos chachapoya de enterrar algunos de sus muertos en el interior de las viviendas. ${ }^{29}$

\section{Juanitapampa (PAJ 196-B)}

El sitio arqueológico Juanitapampa (PAJ 196) formó parte de un gran asentamiento (PAJ 193-198), hoy en dia destruido por las actividades agrícolas y ganaderas. Sus dos sectores (A y B) cubren un área de aproximadamente dos hectáreas. Juanitapampa se ubica encima de una meseta a una altura de 26122633 msnm (Fig. 3), cerca de un camino que desciende hacia el «Pueblo de los Muertos» (PAJ 70). El sitio consta de un total de 14 estructuras circulares u ovaladas, de los cuales siete se encuentran en un pequeño bosque (sector A) y los restantes en el borde de la meseta donde crecen pequeños arbustos (sector B).

Seis de los siete edificios circulares (No. 8-13) del sector B se ubican en fila encima de una terraza de unos $120 \mathrm{~m}$ de largo (Fig. 11). Su muro de contención tiene una altura de más de $1 \mathrm{~m}$ y muestra una escalinata con 5 peldaños en la parte sur que sirvió para acceder a la terraza principal. Los edificios son muy similares a los de Chichita, pero se encuentran en mal estado de conservación. Solamente tres estructuras (edificios 8, 9 y 13) mantienen su contorno completo. Tienen un diámetro de 5,2-7,2 $m$ y muestran un acceso en la parte noreste del recinto. La altura máxima de una de las estructuras (edificio 8) es de 2,9 m. Los muros tienen un ancho de 0,25-0,50 m. Fueron levantados con piedras areniscas, unidas con un mortero arcilloso de color marrón-rojizo. Contiene paja y muchos fragmentos de cerámica. En el paramento interior de los edificios se observan ganchos de madera y huesos de animal (mandibulas de camélido) incrustados. En el interior de dos recintos del sector A (edificios 1 y 7) se registraron nichos con las siguientes dimensiones: 42 x 30 x $35 \mathrm{~cm}$ y 40 x 32 x $35 \mathrm{~cm}$ (ancho/ altura/profundidad). Llevan dinteles de piedra con un largo de $44-50 \mathrm{~cm}$ y una altura de $8-12 \mathrm{~cm}$.

Los vanos de acceso tienen un ancho de $1 \mathrm{~m}$. El umbral de cada edificio está conformado de varias lajas de piedra y no se registraron peldaños semicirculares como en Chichita. Los apisonados se encuentran a la altura de los umbrales.

Excavaciones arqueológicas se realizaron en dos estructuras del sector B. El edificio 13 fue excavado por completo, mientras en el edificio 8 los trabajos se restringieron a la mitad occidental del espacio interior.

28 Los textiles no se conservan por la humedad.

29 En muchos de los edificios circulares de Kuelap se hallaron entierros debajo de los apisonados o en las cámaras subterráneas reutilizadas (observación personal). 


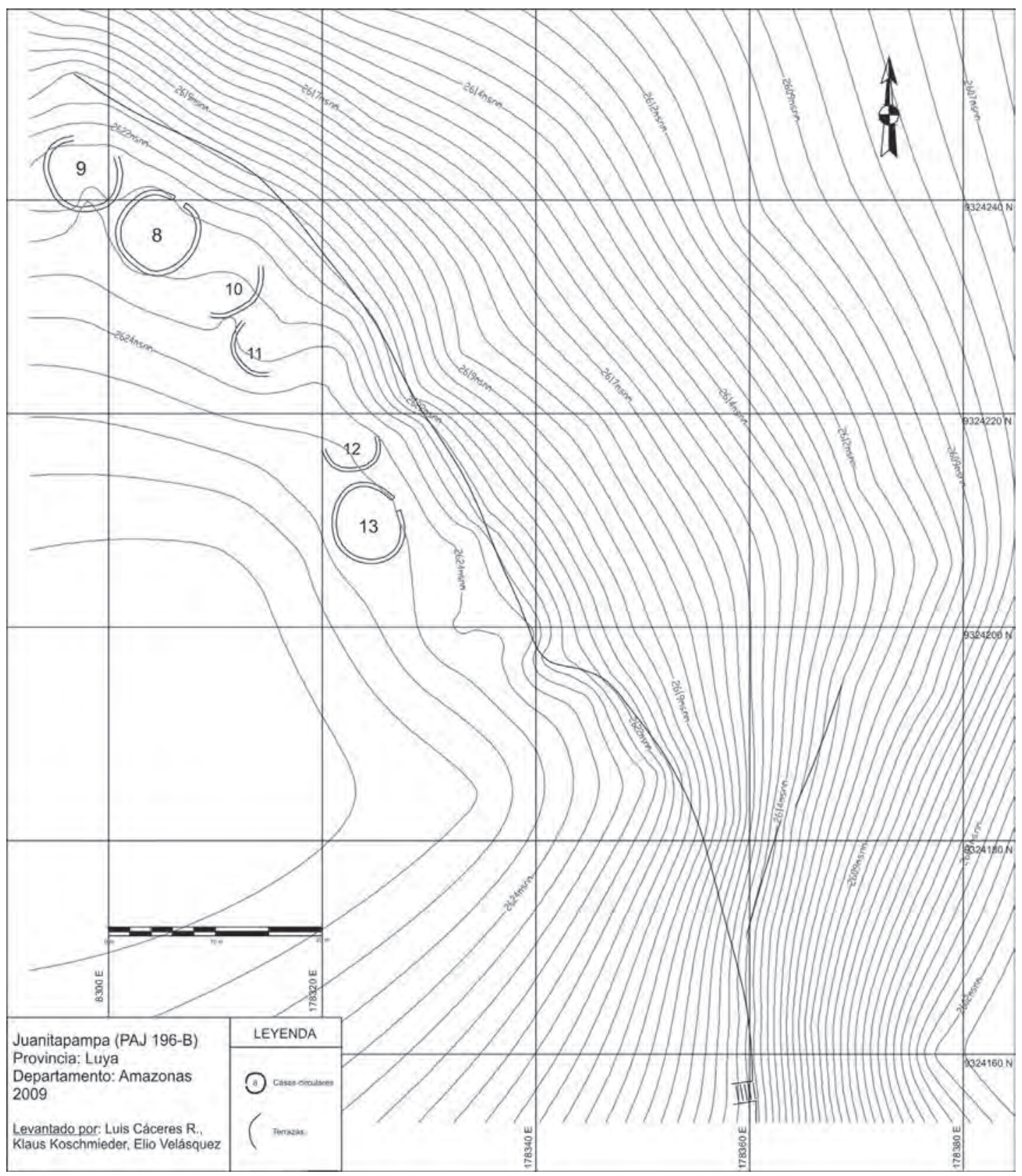

Figura 11. Mapa del sector B del sitio arqueológico Juanitapampa (PAJ 196-B). 
En primer lugar sorprendió la poca estratigrafía encontrada. Encima del único apisonado de cada recinto se acumularon los escombros de los muros desplomados. No se encontraron desechos orgánicos y se recuperaron solamente pocos fragmentos de cerámica. Obviamente los habitantes limpiaron el espacio interior antes de retirarse.

En cada edificio se registró un batán de grandes dimensiones (Edificio $13=1,40 \times 1,00 \times$ 0,30 m; Edificio $8=1,00 \times 0,85 \times 0,25 \mathrm{~m}$ ). Muestran una ligera concavidad. Piedras colocadas debajo de los batanes sirvieron para mantenerles en una posición horizontal. Solamente en el edificio 8 se hallaron manos de moler (manzuelas), las cuales fueron depositadas encima del umbral del acceso. Llamó la atención la ausencia de fogones en el interior de los edificios. Destaca el registro de una construcción semicircular, adosada al muro oeste del edificio 13. Solamente quedaron dos hileras de la base de sus muros, la cuál fue levantada con piedras pequeñas y una mediana al extremo este (Fig. 12). En el interior se observa una capa de barro compacta. Es de suponer que se trató de un pequeño depósito o almacén. Al igual que en Chichita no se registraron banquetas y/o cámaras subterráneas, típicas para Kuelap y otros sitios en el sur.

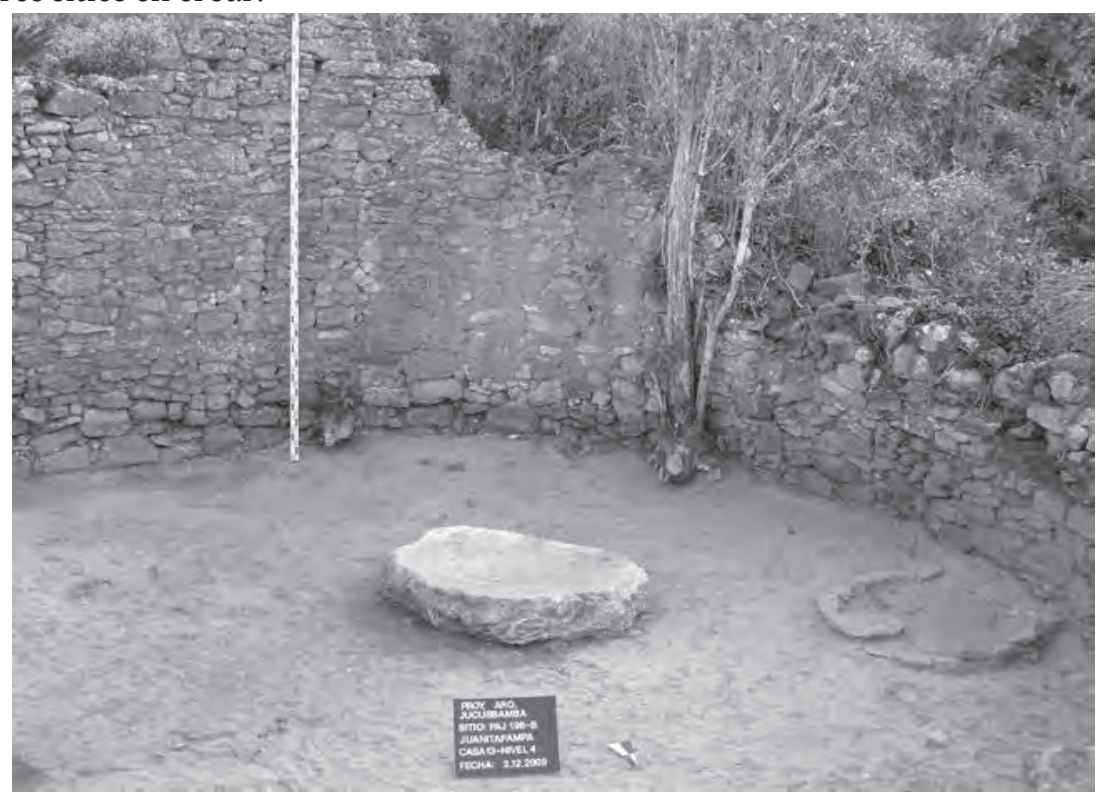

Figura 12. Espacio interior de un edificio circular con batán y posible depósito (Juanitapampa - PAJ 196-B).

La presencia de un solo apisonado y la ausencia de entierros deja suponer que los edificios de Juanitapampa fueron ocupados durante un corto lapso de tiempo.

Otro sitio del complejo Juanitapampa (PAJ 194) está asociado a un corral de camélidos, el cuál cubre un área de $100 \times 40 \mathrm{~m}$. Tres de los siete edificios circulares (No. 1-3) se ubican alrededor del corral (Fig. 13). Sus habitantes probablemente se dedicaron a la cría y vigilancia de los animales. El muro del corral todavía muestra un ancho de 0,6 $\mathrm{m}$ y una altura de $1 \mathrm{~m} .{ }^{30} \mathrm{En}$ el interior del cerco se recuperaron huesos de llamas y alpacas. ${ }^{31}$ No se registraron antiguos campos de cultivo en las mesetas, pero es de suponer que hayan desaparecido por la transformación del paisaje durante los últimos siglos.

30 Otros corrales identificados son más pequeños. Muestran un diámetro de 8 a $15 \mathrm{~m}$.

31 A partir de la colonia los camélidos fueron extinguidos, así que el material óseo no puede proceder de un contexto moderno. 


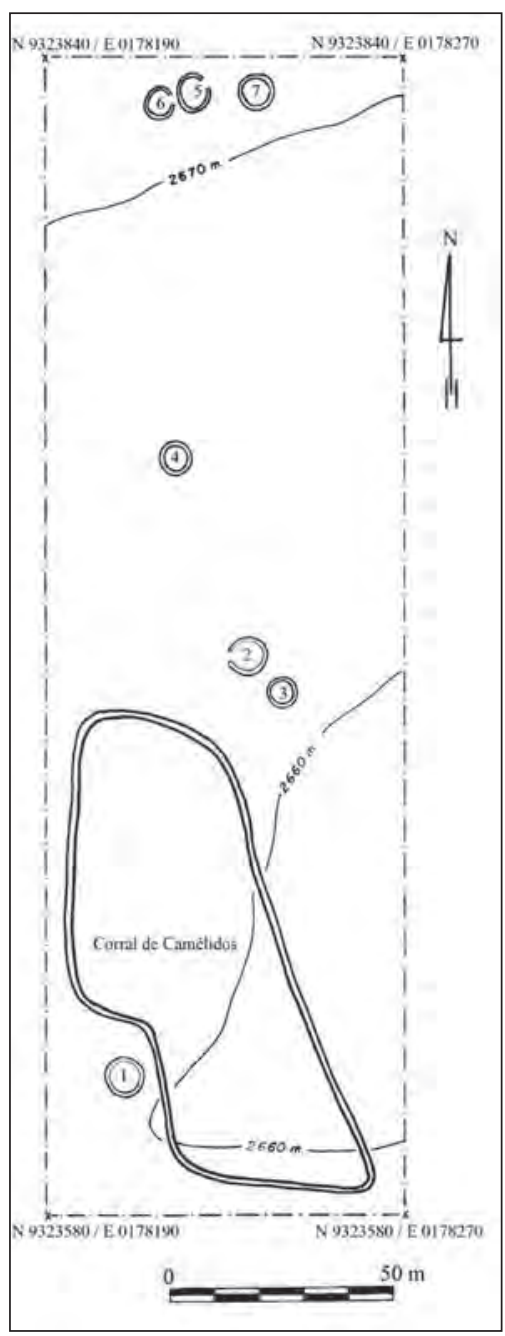

Figura 13. Mapa del sitio PAJ 194 (Juanitapampa) con corral de camélidos y edificios circulares.

\section{Resumen}

Los asentamientos en las cumbres de las montañas tienen un carácter netamente residencial. Los edificios circulares u ovalados sirvieron como viviendas. En el interior se registraron batanes, manos de moler, fogones y desechos orgánicos que provienen de la preparación y del consumo de los alimentos. ${ }^{32}$ Otros rasgos importantes fueron construcciones de piedra como un reservorio de agua (Chichita), un canal de desagüe (Chichita) y un posible depósito (Juanitapampa). No se identificaron banquetas, usualmente interpretadas como lugares para dormir (Schjellerup 2005: 370; v. Hagen 2002: 93). Tampoco se registraron las típicas cámaras subterráneas, revestidas de piedra, que se concentran en Kuelap y otros sitios en las alturas. Sirvieron para guardar y conservar productos agrícolas y protegerles de los roedores y otros animales. En Chichita, al igual que en otros sitios chachapoya (p.ej. Kuelap), se hallaron entierros debajo de los pisos. Parece que entre los grupos chachapoya existió la costumbre de enterrar algunos de sus miembros en el interior de las viviendas. Obviamente no fueron gente de alto rango, cuyos cementerios se ubican en los acantilados.

Al parecer Chichita (PAJ 250) fue ocupado durante un tiempo alargado, ya que se encontraron una estratigrafía compleja con la presencia de varios apisonados superpuestos y una mayor cantidad de entierros (7 entierros - edificio 10), en parte disturbados por la remodelación de los ambientes. Obviamente el sitio de Juanitapampa (PAJ 196-A) fue ocupado durante un período más corto. La presencia de un solo apisonado y la ausencia de entierros en el interior de los edificios, dejan suponer que los edificios sirvieron como viviendas temporales, probablemente durante ciertas actividades en el campo, como la cría de los camélidos.

Los habitantes de los asentamientos residenciales, ubicados en la cima de los cerros, se dedicaron a la agricultura (p.ej. maíz, papa, frijoles), a la recolección de caracoles terrestres, a la caza de animales silvestres (p.ej. venados), a la cría de animales domésticos (camélidos y cuyes), a la produccíon de los textiles, ceramios, metales y a otras actividades artesanales. No se han identificado edificios de carácter ceremonial o administrativo en las cumbres de las montañas.

\section{ASENTAMIENTOS EN LAS LADERAS DE LAS MONTAÑAS}

En las laderas de las montañas se identificaron 24 asentamientos chachapoya con edificios circulares u ovaladas (Fig. 3). En su gran mayoría están asociados con campos de cultivo y con pequeños

32 Los fogones o quemas, documentadas en el espacio interior de las casas de Chichita, son de un tamaño muy reducido. Además no se trata de fogones construidos de piedra (para sostener las ollas). En los edificios de Juanitapampa ni siquiera se registraron fogones. Parece que algunas actividades de cocina se trasladaron al aire libre. De un modo parece inteligible, ya que en una vivienda sin ventanas el humo hubiera afectado la salud de sus pobladores. 
depósitos de forma circular. Excavaciones arqueológicas se realizaron en Pullía (PAJ 157-A), un asentamiento con 15 estructuras circulares $u$ ovaladas, directamente asociado a un sistema de terrazas de cultivo.

El sitio más grande y impresionante en el área de investigación es Kacta (PAJ 237). Sus 44 edificios circulares muestran un acabado especial (enlucidos, pinturas, nichos de gran tamaño). Los recintos, algunos con un diámetro de hasta $12 \mathrm{~m}$, se ubican encima de terrazas largas, originalmente decoradas con frisos. Las excavaciones arqueológicas se llevaron a cabo en 5 estructuras de diferente tamaño (3,3-11,8 m) para averiguar su posible función.

\section{Pullía (PAJ 157-A)}

El sitio arqueológico Pullia (PAJ 157-A) cuenta con un total de 15 edificios de forma ovalada, asociados a campos de cultivo (PAJ 157-B) que se ubican hacia el oeste del asentamiento en la falda de una colina (Fig. 14). Los andenes cubren un área de aproximadamente 450 x 290 m (13 ha) y siguen la topografía natural del terreno. Por tal razón muestran una forma semicircular. Sus muros de contención alcanzan un largo de $35 \mathrm{~m}$ y una altura máxima de más de $2 \mathrm{~m}$.

El asentamiento se ubica a una altura de 2140-2175 msnm en la margen izquierda del rio Utcubamba (Fig. 14). Los edificios se ubican solos o en grupos de hasta cinco estructuras (No. 1-5) encima de unas terrazas artificiales. Son recintos pequeños de forma ovalada con un diámetro entre 3,3 y 5,6 m (Fig. 15). Muestran un acceso estrecho $(0,65-0,80 \mathrm{~m})$ en la parte noroeste o norte del recinto. Los muros más conservados alcanzan una altura de hasta $1,7 \mathrm{~m}$. Son angostos $(0,25-0,40 \mathrm{~m})$ y fueron levantados con piedras areniscas, unidas con un mortero arcilloso de color marrón-rojizo. La base de los muros, especialmente cerca del acceso, consiste en piedras de gran tamaño, que alcanzan un largo de 0,8 m, una altura de 0,5 $\mathrm{m}$ y un ancho de 0,4 m. Por la poca altura de los muros se registró un solo nicho en el paramento interior de uno de los edificios (No. 7). No se identificaron ganchos de madera, huesos o astas de venado en las paredes.

Las excavaciones arqueológicas se realizaron en el espacio interior de tres edificios ovalados. Muestran un diámetro de 5,5 x 3,9 m (edificio 4), 3,8 x 3,6 m (edificio 7) y 5,6 x 4,5 m (edificio 8). El edificio 4 se ubica con otros recintos encima de una terraza alargada, mientras cada uno de los edificios 7 y 8 fue construido sobre una terraza individual. La elevación artificial del edifico 7 consiste en un embasamiento semicircular que sirvió como base para la construcción de la estructura. Muestra una altura máxima de 0,6 m. Delante del acceso del edificio queda un espacio de $1 \mathrm{~m}$ de ancho que sirvió como pasarela (Fig. 15).

El espacio interior de los tres edificios fue excavado por completo. En cada una de las estructuras se definió un solo apisonado de barro que se ubica a la altura del nivel superior del umbral. Este consiste de 4-5 lajas de piedra, unidas con un mortero arcilloso (Fig. 15). Todos los accesos están conformados por dos piedras grandes, plantadas verticalmente. En un caso (edificio 7) las piedras tienen un alto de 0,8-1,0 m.

No se encontraron desechos orgánicos en el espacio interior de los edificios, tampoco batanes, manos de moler o fogones. Se recuperaron solamente pocos fragmentos de cerámica diagnóstica. El único rasgo especial consistió en una banqueta que muestra un muro de contención de $3 \mathrm{~m}$ de largo y 0,40-0,45 $\mathrm{m}$ de alto. Se identificó en la parte trasera del edificio 7 (Fig. 15). El ancho de la banqueta es de $1 \mathrm{~m}$.

Al parecer los edificios de Pullía (PAJ 157-A) sirvieron como viviendas temporales durante los trabajos en los campos de cultivo (períodos de la siembra y cosecha). Es de suponer que los trabajadores traían sus provisones y no cocinaron in situ. Esto explicaría la ausencia de batanes, manos de moler y fogones en el espacio interior de los edificios. Es de suponer que los edificios pequeños y sencillos sirvieron básicamente para descansar (banqueta) y para guardar las herramientas. 


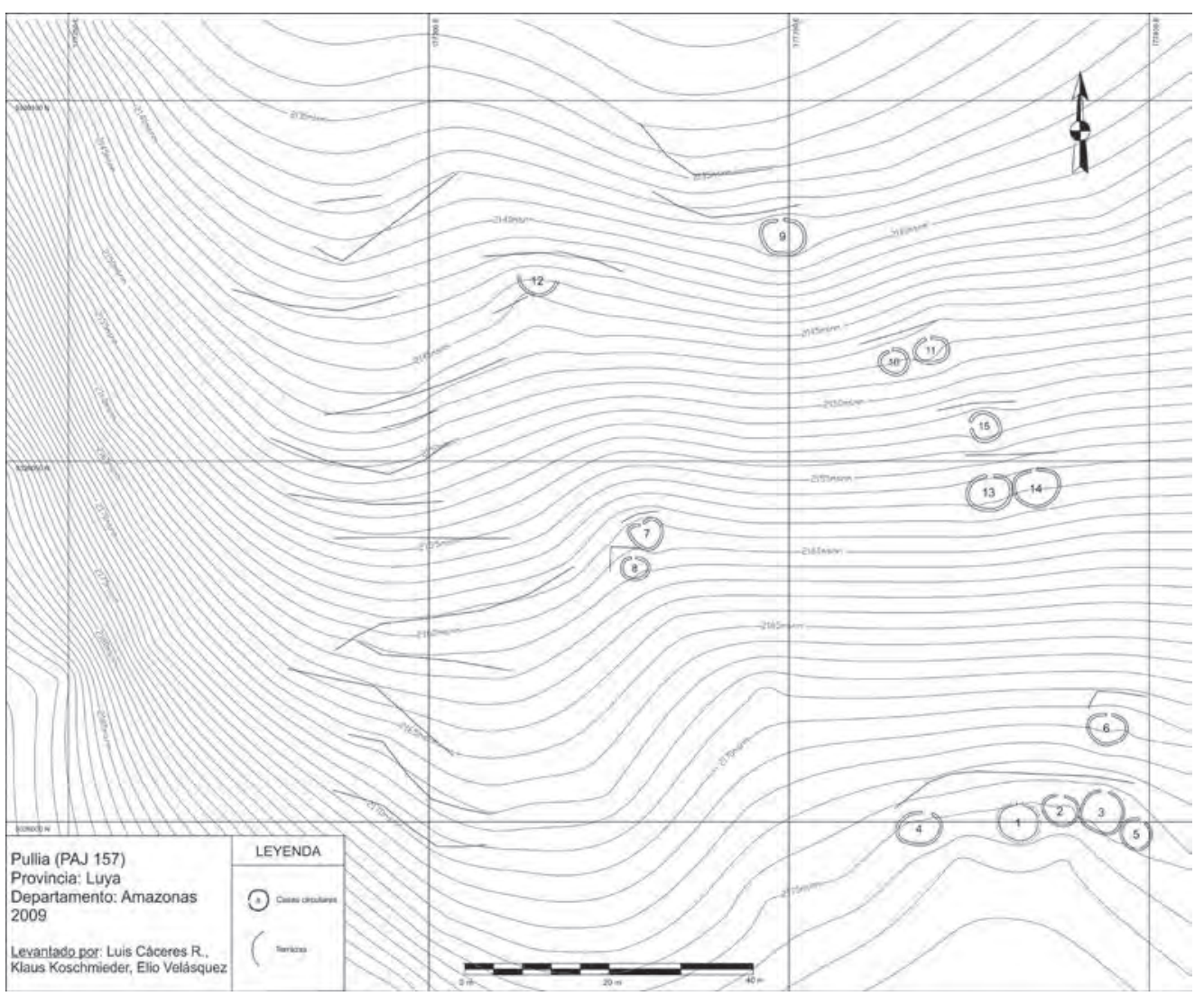

Figura 14. Mapa del sitio arqueológico Pullía (PAJ 157).

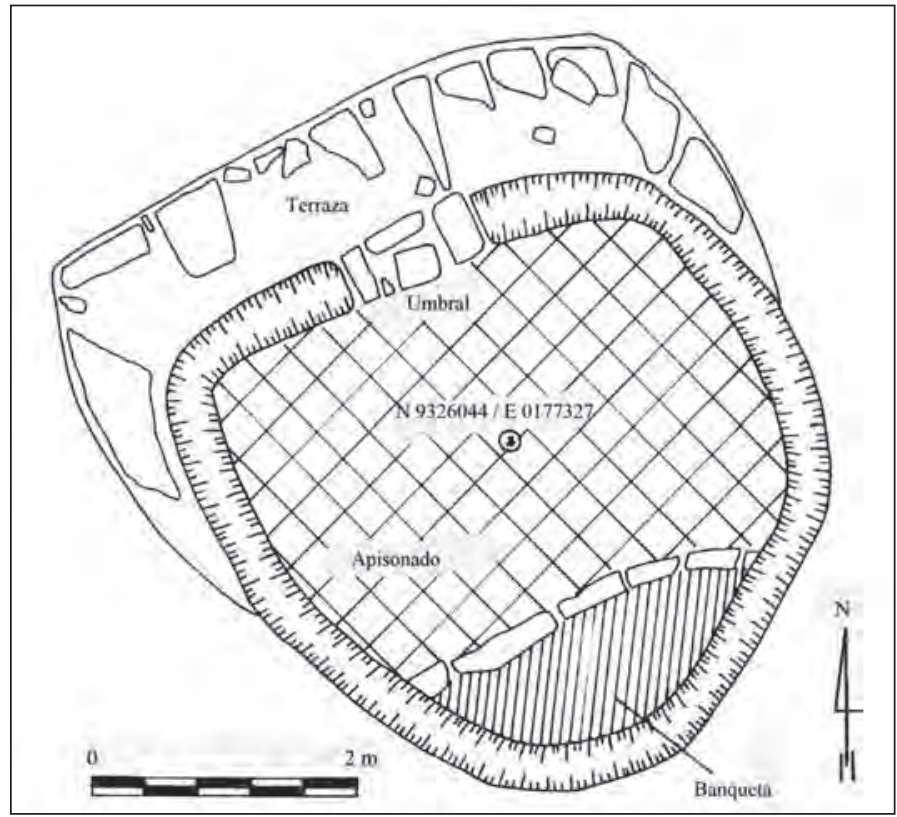

Figura 15. Dibujo de planta (Edificio 7 Pullía - PAJ 157-A). 


\section{Corralpampa (PAJ 93)}

En Corralpampa los campos de cultivo están asociados con un conjunto de recintos circulares pequeños. Los más grandes, con un díametro de 3,0-4,0 m, muestran una entrada, mientras las estructuras menores (D: 1,6-3,0 m) carecen de un acceso directo. Al parecer se trata de antiguos depósitos. En dos de los sectores del sitio arqueológico Corralpampa (PAJ 93-E-F) se registraron más de 30 depósitos que se distribuyen en un área de 3 hectáreas (Fig. 16). Los muros de piedra muestran un espesor de 0,45-0,55 $\mathrm{m}$ y mantienen una altura de hasta $1,5 \mathrm{~m}$. Parece que las construcciones sirvieron como «almacenes temporales» para guardar productos agrícolas durante un corto lapso de tiempo, ya que los cereales no se conservan por mucho tiempo a estas alturas (2100-2200 m). Allí se almacenaron

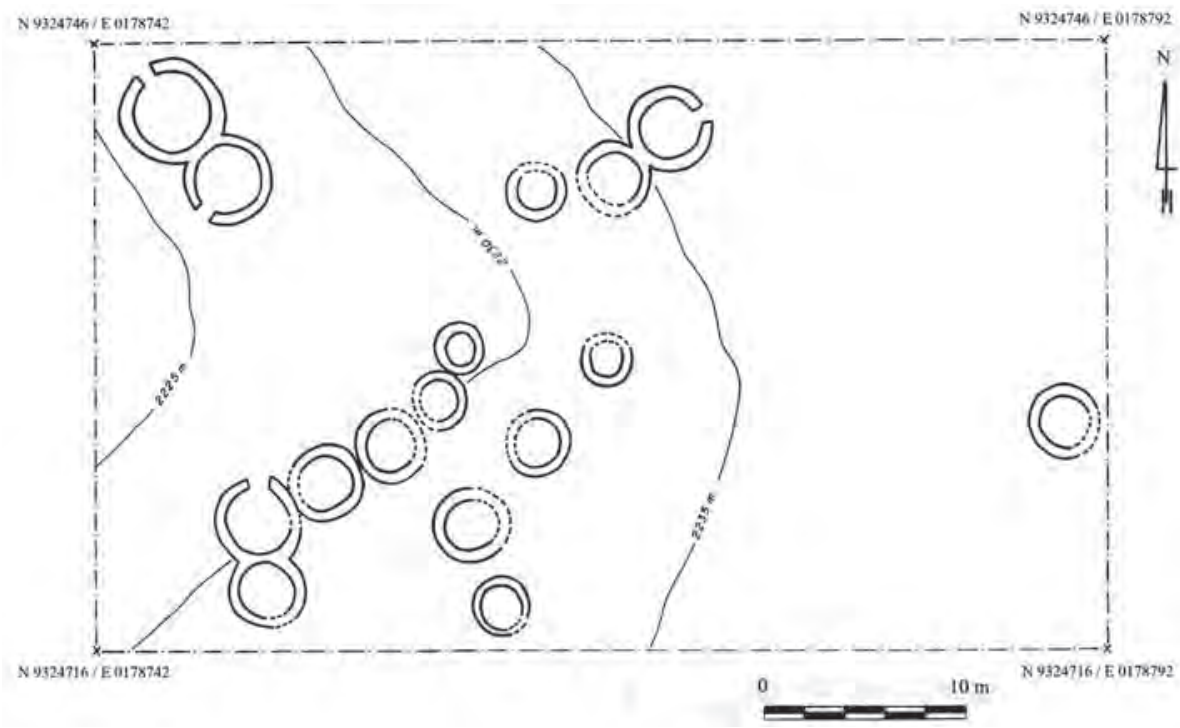

Figura 16. Estructuras circulares y depósitos (Corralpampa - PAJ 93-E).

las cosechas antes de transportarles hacia los asentamientos en las cumbres de las montañas. En Corralpampa (PAJ 93-C) existe un asentamiento con edificios muy similares a los de Pullía ${ }^{33}$, donde permanecían los trabajadores durante los trabajos de campo. Interesante es la presencia de una estructura circular encima de una roca (PAJ 93-B), la cuál podría haber servido como un punto de control (Fig. 17), ya que se ubica entre dos áreas con depósitos. El recinto curioso tiene un diámetro de $2,4 \mathrm{~m}$ y presenta un vano de acceso de 0,6 $\mathrm{m}$ de ancho. Sus muros alcanzan un alto de $0,75 \mathrm{~m}$ y un espesor de 0,40 m. Todo el complejo de Corralpampa (PAJ 93-A-F) cubre un área de 17 hectáreas.

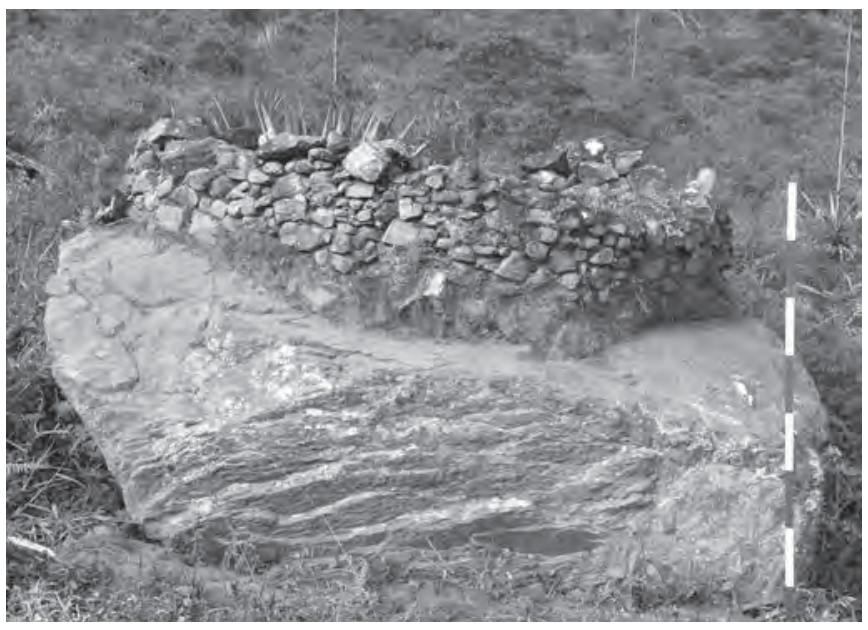

Figura 17. Estructura circular sobre roca (Corralpampa - PAJ 93-B).

33 Los edificios circulares de Corralpampa (PAJ 93-C) tienen un diámetro promedio de $4 \mathrm{~m}$. 


\section{Kacta (PAJ 237)}

Kacta (PAJ 237) es el sitio arqueológico más grande en la zona de investigación. Sus 44 edificios registrados se distribuyen desde la orilla del río Jucusbamba hasta el borde de la meseta (2320-2520 msnm). El asentamiento cubre un área de 35 hectáreas, que fue subdividido en 4 sectores (A-D). Los sectores A-C se ubican por encima de la carretera que conduce del pueblo de Lámud a Quilaylón-Ayachaqui. El sector A (23 edificios) abarca la parte sur del sitio arqueológico (Fig. 18), el sector B (10 edificios) la parte noreste y el sector C (4 edificios) la parte noroeste. Las estructuras que se distribuyen desde la carretera hasta el río Jucusbamba pertenecen al sector D (7 edificios). Por lo general los edificios forman pequeños grupos de 2 a 6 estructuras, levantadas en fila encima de unas terrazas artificiales. Estas terrazas tienen un largo de hasta $150 \mathrm{~m}$ (Sector A - edificios 8-12) y una altura máxima de 2,4 m. Una de las terrazas muestra todavía un friso de $7 \mathrm{~m}$ de largo en forma de zigzag (Fig. 19). Encima de esta terraza se ubica el recinto más grande de Kacta (Sector A - edificio 13).

Las terrazas artificiales se levantaron para la construcción de los recintos circulares, pero también se modificaron las rocas naturales que se ubicaron detrás de los edificios. Los recintos de Kacta fueron levantados con areniscas margosas, areniscas calcáreas (calcarenitas), areniscas cuarzosas, calizas margosas y calizas micríticas (Vásquez 2008), unidas con una argamasa calcárea y arcillosa que contiene numerosos fragmentos de cerámica. Los muros están construidos de pequeñas piedras y ascienden en forma de espiral (ver Gil 1938: 133). Tienen un espesor de 0,25-0,60 cm y alcanzan una altura máxima de 5,7 m (Koschmieder 2012: 71). Langlois (1939: 56) observó una ligera inclinación de los muros hacia el interior y escribió que «esta inclinación ... hacia la parte alta pudiera inducir a imaginar el encorvamiento de una bóveda o si se prefiere de una cúpula». Gil (1938: 134) hizo una reconstrucción hipotética de los edificios, pero es poco probable que hayan tenido cúpulas de piedra y barro, ya que este tipo de construcción es inestable en una zona sísmica.

En el paramento interior de los edificios se observan una serie de huecos (de sostén para las vigas de madera), ganchos de madera (huacalas) así como mandíbulas de camélidos y astas de venado incrustadas. Los muros fueron revestidos con un enlucido de arcilla blanquizca, el cuál subsiste áun sobre grandes superficies. El edificio 17 fue decorado con una pintura mural. Los recintos muestran hasta una docena de nichos en el paramento interior. En los recintos pequeños y medianos (D: 3,5-7,0 m) tienen una dimensión de $25 \times 18 \times 18 \mathrm{~cm}$ a $68 \times 25 \times 24 \mathrm{~cm}$, mientras en los edficios grandes (D: $7,0-11,8 \mathrm{~m}$ ) miden de $60 \times 40 \times 30 \mathrm{~cm}$ a $98 \times 50 \times 36 \mathrm{~cm}$ (Fig. 20). Tienen una pared de fondo muy delgado, elaborada de cañas y revestida de un enlucido de barro. Los pequeños nichos llevan un dintel de piedra, los grandes un dintel de madera. Por lo general los vanos de acceso se ubican en la parte occidental de los edificios que hace frente al valle. ${ }^{34}$ Tienen un ancho de 0,70-1,25 m y muestran un umbal, conformado por varias lajas de piedra.

Las excavaciones arqueológicas se realizaron en el espacio interior de 5 estructuras circulares. Se trata de dos edificios de gran tamaño (Sector A - edificio 13 - D: 9,8-11,8 m; Sector B - edificio 17 - D: aprox. 7,9 m), dos edificios de tamaño medio (Sector A - edificio 11 - D: 5,3-6,7 m; Sector C - edificio 31 - D: 4,8-5,2 m) y una pequeña estructura (Sector A - edificio 16 - D: 3,6 m). Tres edificios fueron excavados por completo (No. 11, 16, 31), mientras en los edificios de gran tamaño (edificios 13, 17) se realizaron cateos. Según nuestra hipótesis edificios de diferente tamaño deben haber cumplido diferentes funciones.

\section{Edificio 16 (Sector A)}

El edificio 16 es uno de los recintos más pequeños de Kacta (Fig. 18). Se ubica encima de una terraza artificial y fue adosado a la roca natural. Tiene un diámetro de 3,6 m. La estructura fue excavada por

34 Solamente tres de los 44 edificios de Kacta tienen su acceso en la parte sur (edificios 26, 31) u oeste (edificio 7). 


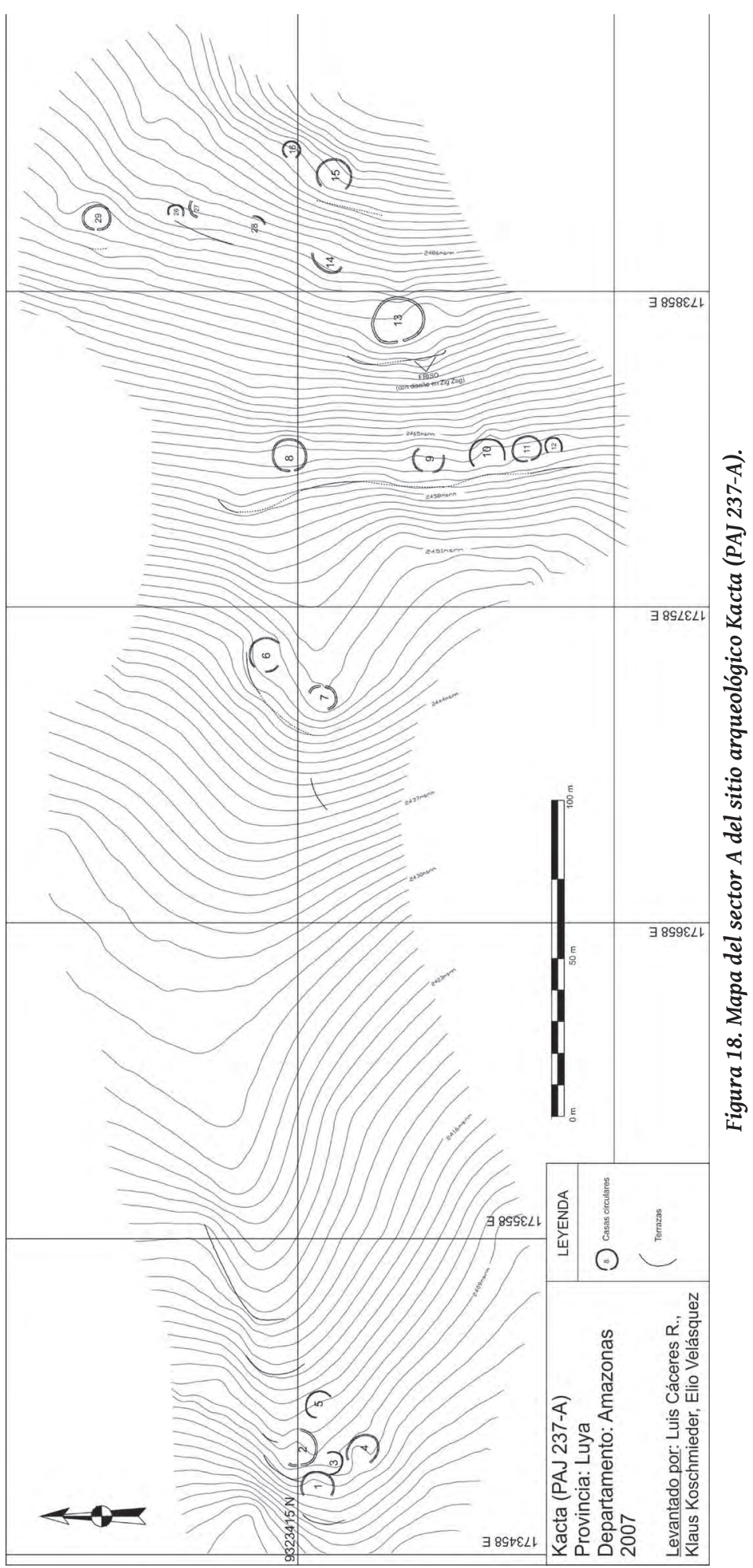




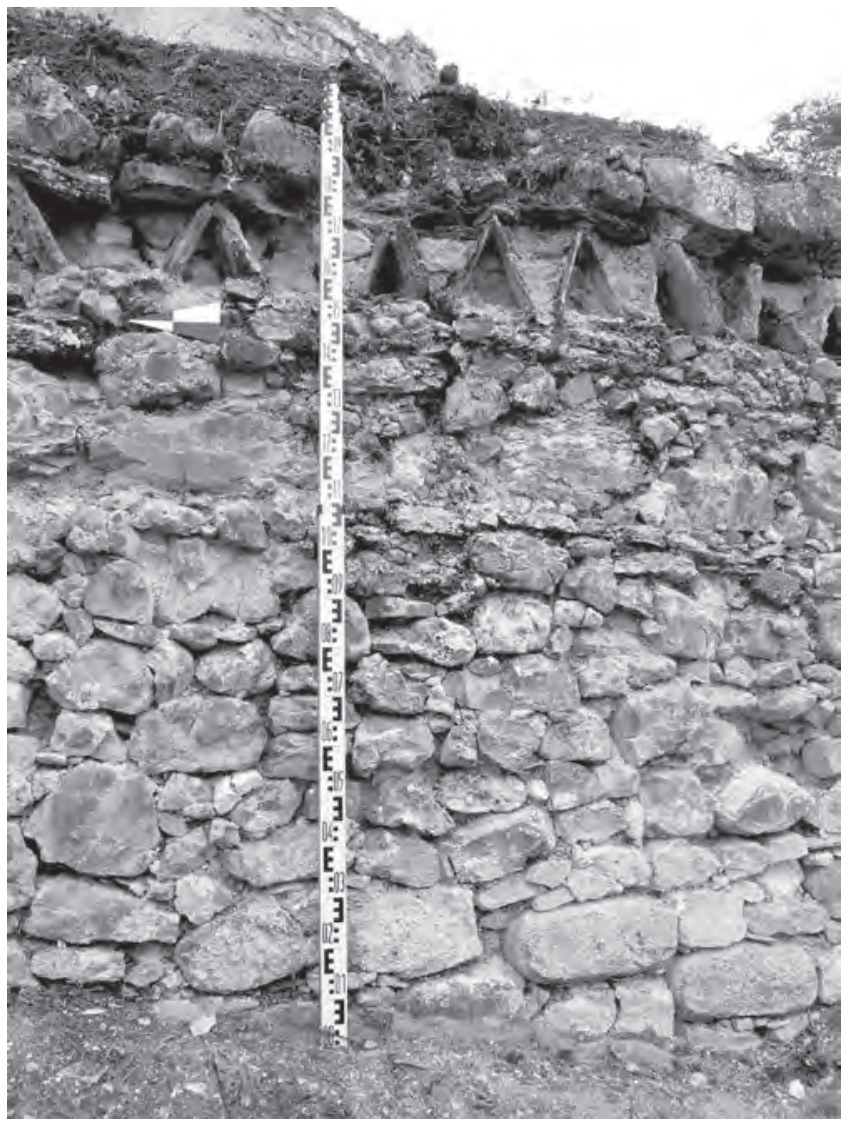

Figura 19. Friso en forma de zigzag en la parte superior de un muro de contención (Kacta - PAJ 237-A).

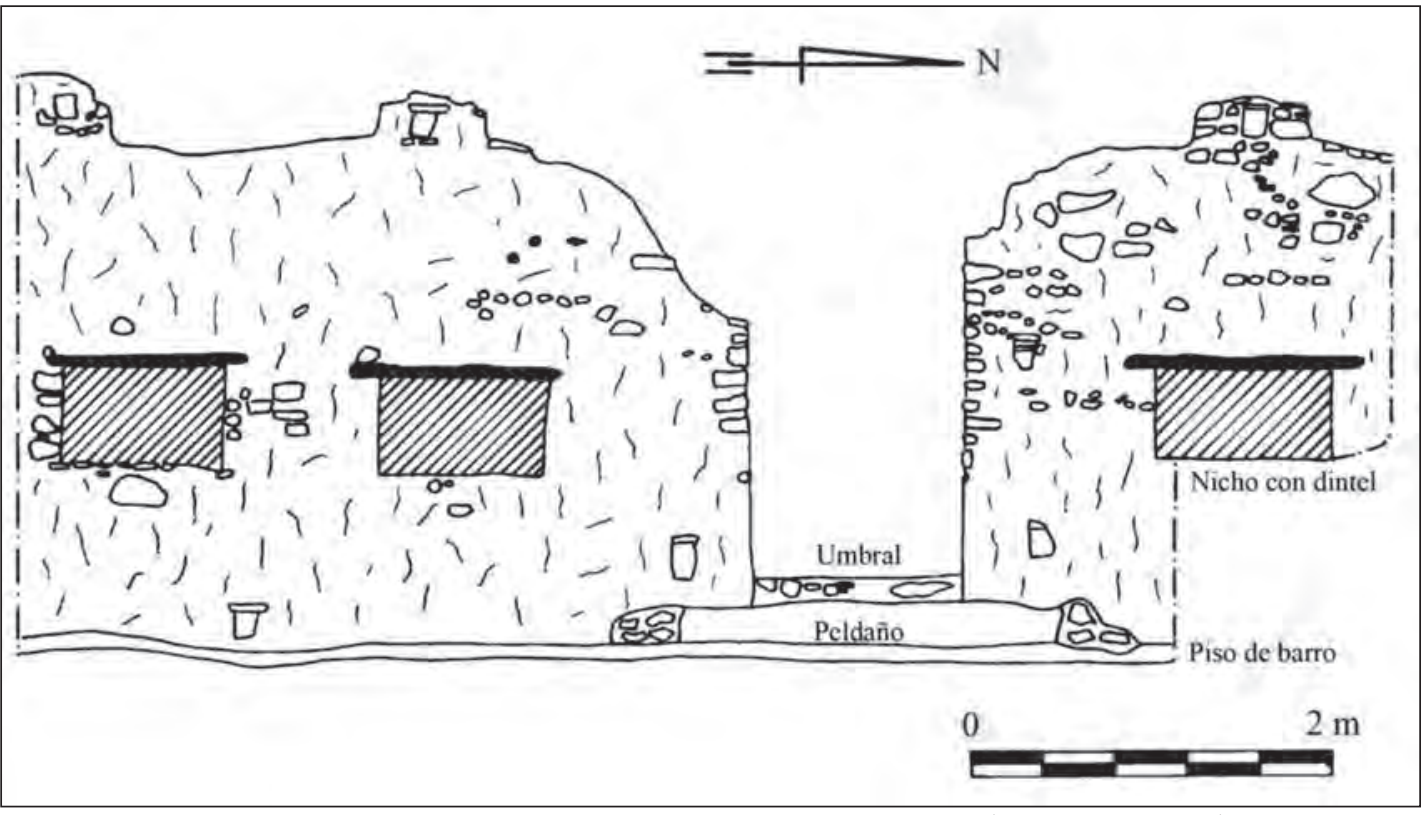

Figura 20. Perfil oeste del edificio 13 con nichos de gran tamaño (Kacta-PAJ 237-A). 
completo. En su interior se hallaron un batán, un fogón y el entierro de un neonato. El batán muestra una forma irregular (aprox. 0,8 x 0,6 x 0,2 m) con una superficie casi plana. Fue elaborada de una roca arenisca calcárea y se ubica adosada a la roca natural que forma la parte trasera del recinto. Hacia su lado norte se registró un fogón simple. Restos orgánicos en los alrededores del batán y del fogón dejan suponer que la estructura sirvió como cocina. Debajo del apisonado, cerca al acceso, se halló una fosa circular (D: 0,6 m, prof.: 0,4 m) que contenía los restos óseos de un bebé. No se registraron ofrendas.

\section{Edificio 11 (Sector A)}

El edificio 11 se ubica encima de la terraza más larga de Kacta, junto con otras cuatro estructuras (Fig. 18). Se encuentra en buen estado de conservación. Tiene una forma ovalada con un diámetro de 5,5-6,5 m. En el paramento interior, cerca al acceso, se observaron varios nichos de tamaño medio. El vano del acceso tiene un ancho de $1 \mathrm{~m}$ y todavía una altura de 1,8 $\mathrm{m}$. Las excavaciones se realizaron en todo el interior del edificio. Se identificó un solo piso de barro bién conservado y abandonado en forma limpia (Koschmieder 2012: 72). Se ubicó a la altura del umbral. No se encontraron otros rasgos en el espacio interior del recinto, el cuál, al parecer, sirvió como vivienda temporal.

\section{Edificio 31 (Sector C)}

Este edificio se encuentra cerca del camino que conduce de Lámud a Ayachaqui. Es de un tamaño medio con un diámetro de 4,8-5,2 m (Fig. 21). Su acceso, con un ancho de $1 \mathrm{~m}$, se ubica excepcionalmente en el lado sur. Esta situación se debe a la remodelación del terreno. Debajo del apisonado de la estructura, cerca al vano de acceso, se localizó un muro de contención (Altura: 1,15 m), el cuál sirvió para la construcción de una terraza de un edificio más antiguo (edificio 32). Posteriormente la terraza se amplió hacia el noreste y noroeste para poder erigir el nuevo edificio (No. 31). Al parecer por no querer invertir más trabajo en la construcción de la terraza nueva, el vano de acceso fue colocado en el lado sur del recinto. Las excavaciones arqueológicas se realizaron en todo el interior del edificio. Se registraron un apisonado en mal estado de conservación, sobre el cuál se hallaron un batán, algunas quemas, fragmentos de cerámica y una regular cantidad de restos orgánicos. El batán $(0,70$ x 0,65 x $0,25 \mathrm{~m}$ ) fue elaborado de una roca caliza micrítica y presenta una superficie plana de alta dureza. Como de costumbre, se ubicó en la parte trasera del edificio, asociado con quemas y restos orgánicos. El edificio sirvió para fines domésticos.

\section{Edificio 13 (Sector A)}

El edificio 13 es el más grande de Kacta. Tiene una forma ovalada con un diámetro de 9,8$11,8 \mathrm{~m}$. Se ubica encima de una terraza de $30 \mathrm{~m}$ de largo (Fig. 18), la cuál todavía muestra en su borde superior parte de su friso original en forma de zig-

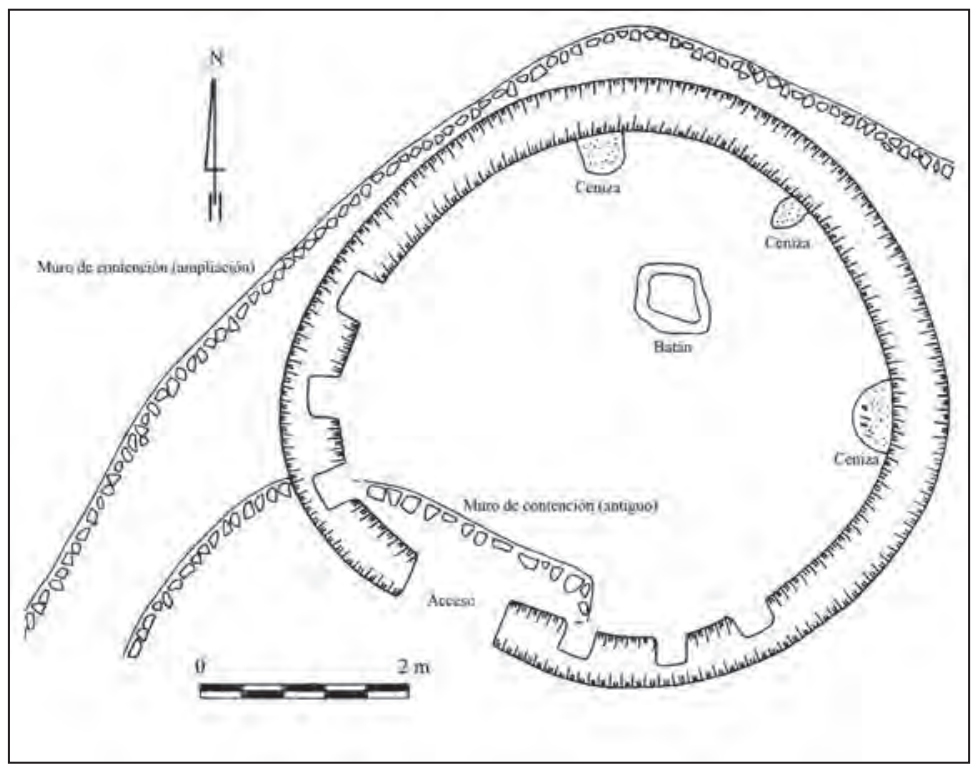

Figura 21. Dibujo de planta (Edificio 31 - Kacta - PAJ 237-C) 
zag (Fig. 19)..$^{35}$ Se trata de una banda horizontal con lajas de piedra que presenta lineas quebradas continuas a un largo de $7 \mathrm{~m}$. El friso mide $20-32 \mathrm{~cm}$ de alto. ${ }^{36} \mathrm{El}$ vano de acceso se ubica en la parte oeste del edificio. Tiene un ancho de 1,25 $\mathrm{m}$ y una altura actual de 1,4-1,8 m. El muro muestra en la parte sureste todavía una altura de 5,7 m (Koschmieder 2012: 71). En varias partes se observan huecos que sostenían vigas, posiblemente para una especie de desván (o segundo piso). También podrian haber servido para la construcción de un techo cónico de maderos y paja. Los nichos, ubicados cerca del vano de acceso (a una altura de $1 \mathrm{~m}$ sobre el nivel del piso), son los más grandes en Kacta. Tienen un ancho de 90-98 cm, una altura de 50-52 cm y una profundidad de 30-36 cm (Fig. 20).

Se realizaron dos cateos en el interior del edificio 13. El primer cateo ( $3 \times 3 \mathrm{~m})$ se estableció en el centro del espacio interior. El objetivo principal era determinar si existió un poste central para soportar un techo. No se encontraron huellas de poste, pero se definió el piso de barro que cubría el interior del edificio. Se ubica a unos 0,2 $\mathrm{m}$ debajo del nivel del umbral. El otro cateo (aprox. $5 \mathrm{~m}^{2}$ ) se emplazó encima del vano de acceso. El umbral está conformado de varias lajas de piedra y muestra un ancho de $0,5 \mathrm{~m}$. Del nivel del umbral el poblador o visitante bajó unos 10-12 cm hacia el nivel de un peldaño de forma semicircular, muy similar a los de Chichita (Fig. 22). Tiene un largo de $2,7 \mathrm{~m}$ y un ancho máximo de $1,1 \mathrm{~m}$. Se encuentra a unos $10 \mathrm{~cm}$ encima del nivel del piso de barro. Por las excavaciones restringidas no se registraron más rasgos arqueológicos en el interior del edificio. Se supone que existió por lo menos un batán en la parte trasera del espacio interior, ya que se encontró una mano de moler fragmentada (manzuela) cerca del vano de acceso.

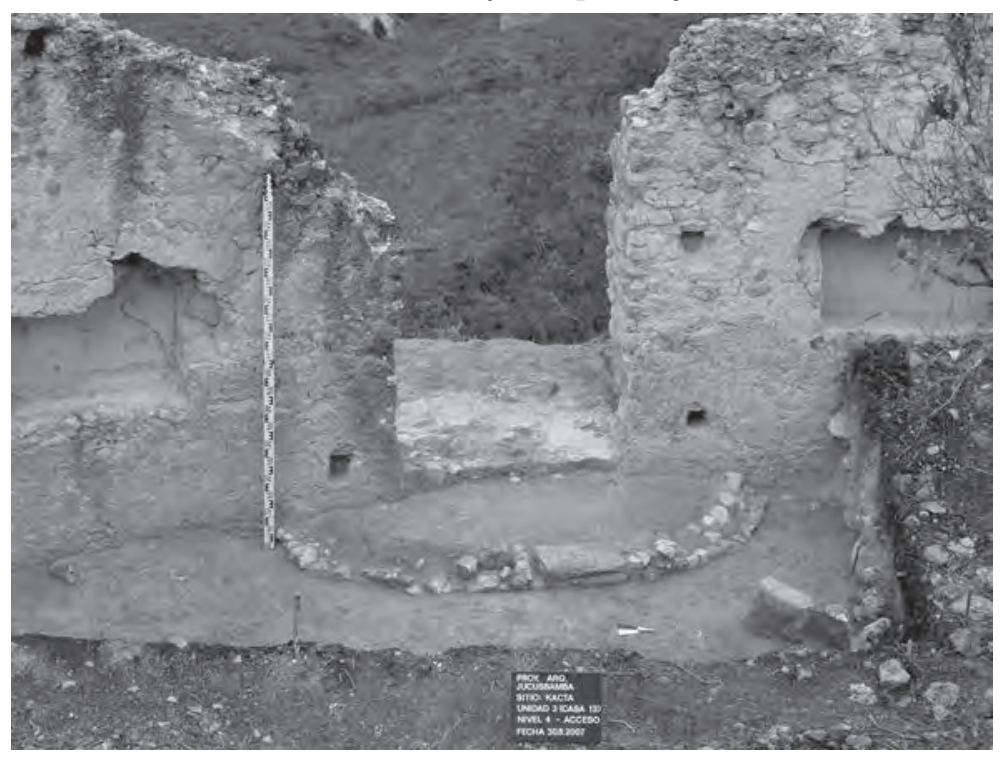

Figura 22. Peldaño en forma semicircular (Edificio 13 - Kacta - PAJ 237-A).

\section{Edificio 17 (Sector B)}

Del edificio 17 queda solamente la parte norte y este del muro (perimétrico), mientras la parte sur y oeste han desaparecido. Por tal razón no se ha podido definir el vano de acceso. Curiosamente el muro noreste todavía mantiene una altura máxima de 4,9 m y muestra un enlucido fino en su paramento interior con la representación de la pintura mural más conspicua que existe en el territorio chachapoya $^{37}$. La escena principal muestra un total de 15 personajes que miran de frente y están agarrados de las manos - un hombre le sigue una mujer y viceversa. Los hombres, desnudos, llevan un tocado en la cabeza y un pectoral con láminas colgantes (en forma de cuchillos) en el pecho, mientras las mu-

35 Según Langlois (1939: 54) la terraza más larga (con los edificios 8-12), que el llamó «andén A», también presentó un friso en forma de zigzag. Este ha desaparecido.

36 El friso está conformado por areniscas calcáreas y cuarzosas. Solamente pocas lajas utilizadas proceden de calizas bituminosas, muy similares a las piedras pizarras (Vásquez 2008).

37 Una primera documentación de la pintura mural fue realizado por Kauffmann y su equipo de investigadores (Kauffmann/Ligabue 2003: 439-444). 
Figura 23. Reconstrucción parcial de una pintura mural (Edificio 17 - Kacta - PAJ 237-B).

jeres, vestidas, se cubren con una especie de montera o gorro y llevan dos tupus que cuelgan del pecho (Fig. 23). ${ }^{38}$ Los personajes tienen un alto de $0,85-1,15 \mathrm{~m}$ y muestran extremidades (brazos, piernas) muy reducidas, mientras las cabezas y los tocados aparecen demasiado grandes. Las figuras fueron pintadas con un total de 4 colores, que son tres tonalidades de un mineral rojo (hematita) y el blanco-gris que proviene de una sustancia llamada colpar. El fondo de las pinturas consiste en el enlucido de color beige. Al parecer la pintura mural representa un ritual o una danza.

Se excavó un área de $20 \mathrm{~m}^{2}$ en la parte noreste del edificio 17 (donde se ubica la pintura mural)

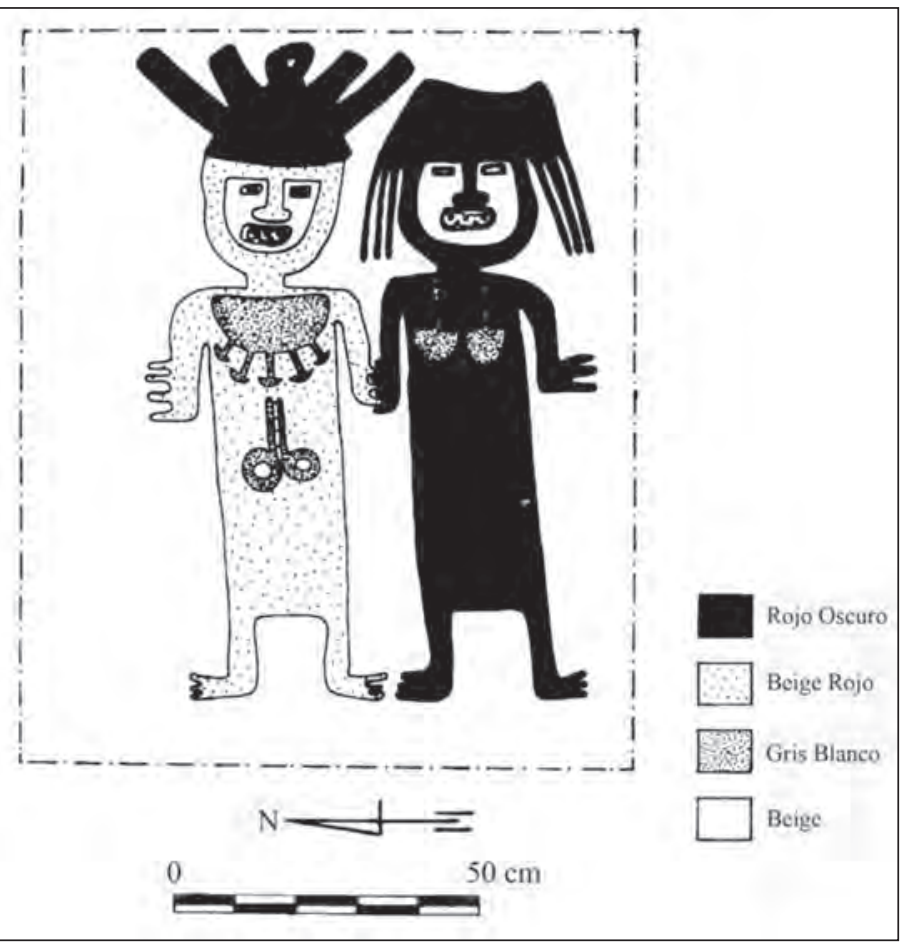
para tratar de esclarecer la función de este gran recinto (D: aprox. 7,9 m). Durante las excavaciones se registraron dos batanes, dos fogones, una construcción semicircular de piedra, dos fosas (tumbas) y un cántaro grande (Fig. 24). Los dos batanes, elaborados de areniscas calcáreas, muestran concavidades pronunciadas y un tamaño de 1,35 x 1,10 m y 1,00 x 0,85 m respectivamente. ${ }^{39}$ Una extraña construcción semicircular, adosada a la pared del edificio muestra un muro de contención con un ancho de $12-20 \mathrm{~cm}$ y un alto de $20 \mathrm{~cm}$. Fue rellenada con lajas de piedra pizarra. Su función no está claro (depósito?). Hacia el este y oeste de la estructura se ubicaron dos fogones con piedras, las cuales posbiblemente sirvieron como soporte para colocar las ollas. Un cántaro con base redonda (D: $38 \mathrm{~cm}$, Alto: $44 \mathrm{~cm}$ ), colocado en una rotura circular del piso, se halló al oeste del fogón más grande.

Cerca de los batanes se identificaron dos fosas (D: $80 \mathrm{~cm}$ ), rellenadas con piedras, que interpretamos como tumbas. Éstas contenían solamente unas falanges de los individuos originalmente enterrados en este lugar, y pocas ofrendas restantes (un tupu de cobre y los restos óseos de varios cuyes). Al parecer los restos mortales de los personajes fueron exhumados posiblemente para llevarlos a unos sarcófagos cercanos (San Antonio), que se ubican en los acantilados enfrente de Kacta. ${ }^{40}$ Es de suponer que la escena, plasmada encima del enlucido de la pared, representa un ritual, relacionada a los funerales que se llevaron a cabo en este edificio. No sabemos a cuál de los eventos funerarios (la inhumación o la exhumación) se refiere la escena pintada, pero parece obvio que el recinto circular de

38 Estos atributos encontramos también en los sarcófagos decorados. Los sarcófagos para hombres muestran un pectoral con cuchillos o tumis a la altura del pecho, mientras los sarcófagos para mujeres fueron decorados con tupus colgantes (Koschmieder 2012: 109).

39 No se ha podido definir el grosor de los batanes, ya que se hallaron semienterrados.

40 En varios sitios con sarcófagos se identificaron entierros secundarios. Se trata de los restos de pequeños fardos que contenían el cráneo y los huesos largos de un individuo, amarrados con soguillas de fibra vegetal. Frecuentemente faltaron los huesos de menor tamaño (Koschmieder 2012: 58; Koschmieder/Gaither 2010: 10). 


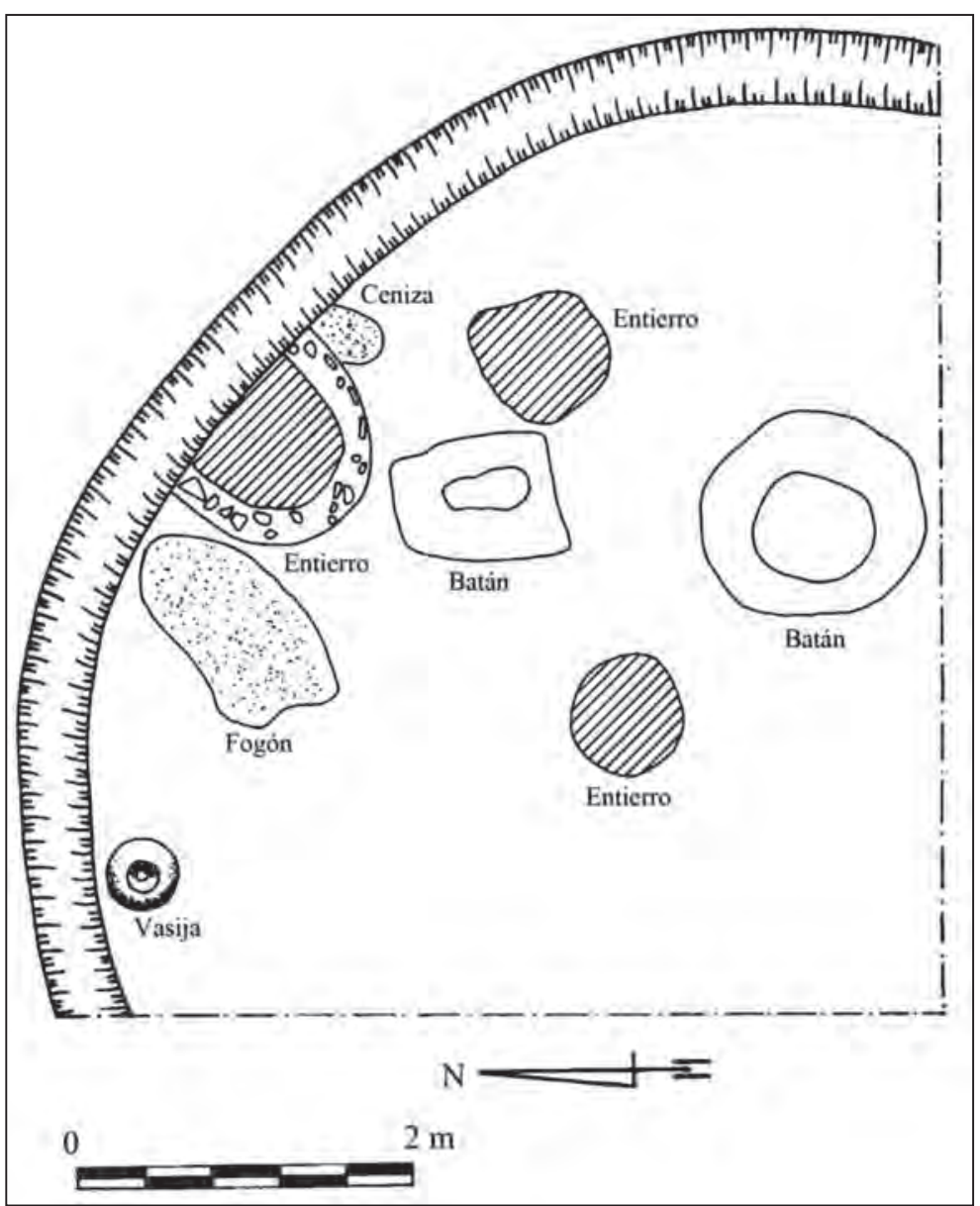

Figura 24. Cuadrícula noreste del edificio 17 con rasgos arqueológicos (Kacta-PAJ 237-B).

grandes dimensiones (patio) no sirvió como vivienda sino para fines funerarios y ceremoniales. Es de suponer que el edificio más grande de Kacta (edificio 13) también sirvió como un espacio público para reuniones importantes, pero solamente con excavaciones en área podriamos verificar esta hipótesis.

\section{Resumen}

Al parecer los asentamientos en las laderas de las montañas fueron habitadas temporalmente. Casi todos los sitios se ubican cerca de los campos de cultivo (terrazas) y depósitos asociados. La sencillez y el tamaño reducido de los edificios circulares u ovalados así como la ausencia de batanes, fogones y desechos orgánicos en su interior (p.ej. Pullía), dejan suponer que sirvieron como posadas temporales, donde los trabajadores descansaron y depositaron sus utensilios y herramientas. Al parecer los sitios fueron frecuentados solamente durante las temporadas de la siembra y cosecha, mientras los asentamientos residenciales por excelencia se ubicaron en las cumbres de los cerros (p.ej. Chichita).

Parece que el único sitio ceremonial en la zona de investigación ha sido Kacta. Allí destacan grandes edificios muy elaborados que con base en nuestros estudios, han sido lugares públicos, donde se realizaron ceremonias, al parecer relacionadas a eventos funerarios. Los visitantes y participan- 
tes pernoctaron en los edificios de tamaño mediano (4,8-6,7 $\mathrm{m}$ ) que interpretamos como «vivendas temporales». Usualmente no presentan «cocinas» (batanes, fogones). Se registraron pisos bién elaborados y grandes nichos, los cuales podrian haber servido para depositar las pertenencias de los visitantes. Podemos considerar los recintos como «dormitorios» o «salas de descanso». Las estructuras más pequeñas muestran un batán y fogones asociados. Al parecer sirvieron como simples cocinas. El espacio reducido no alcanzó para hospedar algunos de los visitantes.

\section{ASENTAMIENTOS CON EDIFICIOS SEMICIRCULARES EN EL ÁREA DE INVESTIGACIÓN}

En el área de investigación se registraron dos docenas de asentamientos con edificios semicirculares (Fig. 3). Se ubican en las bases de los acantilados con sus recintos adosados a la roca natural. Para su construcción se escogieron lugares secos, escondidos y de difícil acceso, probablemente por razones estratégicas. En general, las estructuras semicirculares se encuentran en mal estado de conservación, ya que los muros sufrieron la caida de rocas durante sismos. Algunos de los asentamientos están asociados con sitios funerarios y pinturas rupestres. Se distribuyen a un largo de 100-150 m y muestran los restos de 10-35 recintos. Fueron construidos en fila y se encuentran al borde del abismo, a veces sobre terrazas artificiales como en el caso de Pueblo de los Muertos (PAJ 70-D). Las estructuras tienen un ancho máximo de 3,6-6,5 $\mathrm{m}$ y una altura máxima de 4,5 $\mathrm{m}$ (Pueblo de los Muertos - PAJ 70-D). Los vanos de acceso tienen un ancho de 0,6-1,0 m. Una estructura típica y bién conservada la denominamos Casa Blanca (PAJ 38), ya que en el paramento exterior presenta un enlucido pintado de blanco (Fig. 25). El recinto se ubica aislada debajo de una roca sobresaliente en un lugar seco. El vano de acceso tiene un ancho de 0,8 $\mathrm{m}$ y mantiene una altura de 1,4-1,6 $\mathrm{m}$. La

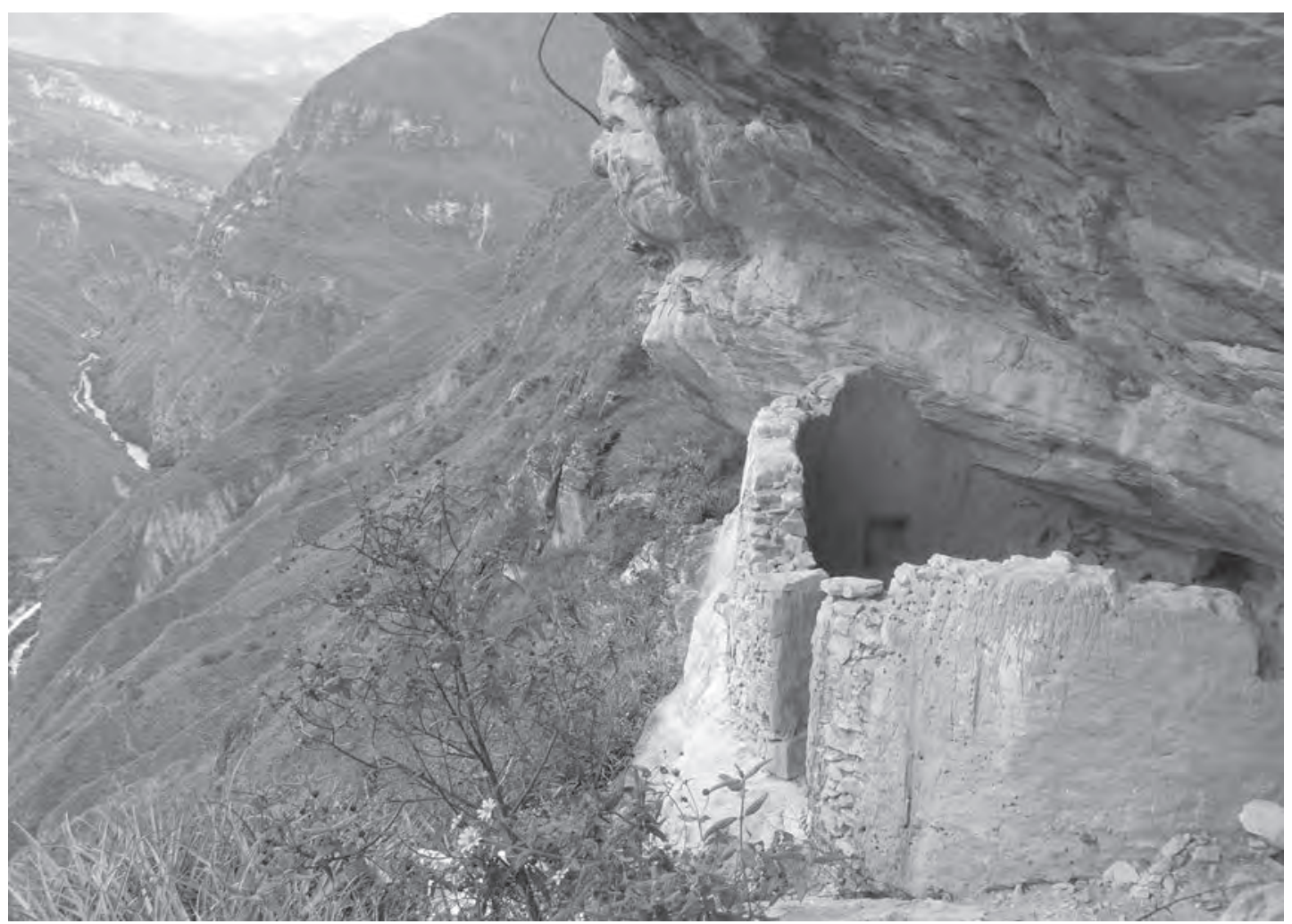

Figura 25. La "Casa Blanca" en la margen izquierda del río Utcubamba (PAJ 38). 
altura máxima del edificio fue de $2 \mathrm{~m}$. Originalmente llevaba un techo horizontal, elaborado de maderos y paja. En el paramento interior se observan varios nichos, mientras al exterior muestra un enlucido blanco. En el espacio interior se observa una banqueta, labrada de la roca natural. Tiene un ancho de $1 \mathrm{~m}$ y un alto de $0,4 \mathrm{~m}$.

Por lo general los muros de las estructuras semicirculares son más estrechos que aquellos de los edificios circulares. Muestran un ancho de 0,25-0,45 $\mathrm{m}$ y fueron levantados con piedras areniscas de diferente tamaño, unidas con una argamasa arcillosa que contiene mucha paja, piedrecillas y fragmentos de cerámica. En el paramento interior fueron fijados ganchos de madera en forma de «V» (huacalas) asi como huesos de animal o astas de venado. En el interior de los recintos se observan nichos, los cuales tienen diferentes tamaños (desde 17 x 14 x $18 \mathrm{~cm}$ hasta 65 × 25 × $18 \mathrm{~cm}$ ). En su gran mayoría llevan un dintel de piedra, pero los más grandes están equipados con un dintel de madera. En Amtia (PAJ 274) se observan nichos grandes en el paramento exterior de uno de los edificios (95 x $28 \times 25 \mathrm{~cm}$ ). Llevan un dintel en forma de cañas. En algunos casos se observan también «ventanas» 0 vanos de luz (p.ej. PAJ 36-B, PAJ 70-D). A veces los muros presentan un enclucido fino con restos de pinturas (p.ej. PAJ 38, PAJ 206-D).

En el espacio interior se hallan con frecuencia batanes, manos de moler, fogones, fragmentos de cerámica, macrorestos vegetales (tusas de maíz, pepas de lúcuma, frijoles, pallares y calabazas) y óseo animal, mayormente de camélidos. Típica es la presencia de banquetas y pequeños depósitos de forma cuadrangular o semicircular (p.ej. PAJ 156).

La vida debajo de las rocas debe haber sido peligrosa, especialmente por los sismos que sacuden periódicamente la región. La caida de las rocas causó la destrucción de varios sitios y consecuentemente la muerte de algunos de sus pobladores. En el sitio de Pucatambo (PAJ 97) se registraron varios entierros en los escombros de las viviendas desplomadas. Los individuos fueron enterrados con ofrendas simples, como bolsas de fibra vegetal, huesos trabajados y cuentas de collar.

\section{«PUEBLO DE LOS MUERTOS» (PAJ 70-D)}

El sitio de «Pueblo de los Muertos» se ubica en un barranco en la margen izquierda del río Utcubamba (Fig. 26). Cubre un área de aproximadamente 6 hectáreas. El sitio fue subdividido en cinco sectores, los cuales se ubican a diferentes alturas ${ }^{41}$ (Sector A: chullpas y sarcófagos originales; Sector B: varios grupos de sarcófagos «restaurados»; Sector C: pinturas rupestres y sarcófagos originales; Sector D: estructuras semicirculares; Sector E: terrazas, pinturas rupestres, sarcófagos originales y «restaurados»).

En el sector D se ubican más de 30 edificios semicirculares, los cuales fueron construidos en fila al borde de un abismo. Para la construcción de los recintos se levantaron terrazas artificiales sobre una estrecha repisa geológica (ancho: 2,0-6,5 m), la cuál se orienta de sur hacia el noreste (Fig. 26) (Koschmieder 2012: 75, 77). En la parte sur del sitio se encuentran los edificios mejor conservados, de los cuales algunos muestran frisos en bajorrelieve (Fig. 27).

Las estructuras semicirculares tienen un ancho máximo de 4,0-6,2 $\mathrm{m}$ y una altura de hasta 4,5 m (edificio 2). Los cuatro vanos de acceso identificados (edificios 1-4), tienen un ancho de $0,9 \mathrm{~m}$ y una altura máxima de 1,8-2,0 $\mathrm{m}$. En los muros se observan «ventanas» (0,45-0,70 x 0,30-0,60 x 0,35-0,45 m), clausuradas con piedras. En el paramento interior se identificaron ganchos de madera (huacalas) y nichos de diferente tamaño que llevan dinteles de madera o piedra. Solamente en «Pueblo de los Muertos» se identificaron frisos en bajorrelieve, plasmados en el enclucido de una banqueta artificial y en el paramento interior de tres edificios. Los relieves tienen una profundidad de 6-12 cm y representan cuatro serpientes y una chakana o «cruz andina» (Koschmieder 2012: 76-77, 123, 139, 141). Tres de las serpientes se encuentran muy estilizadas (Fig. 27). Muestran su cabeza con boca abierta y un cuerpo 


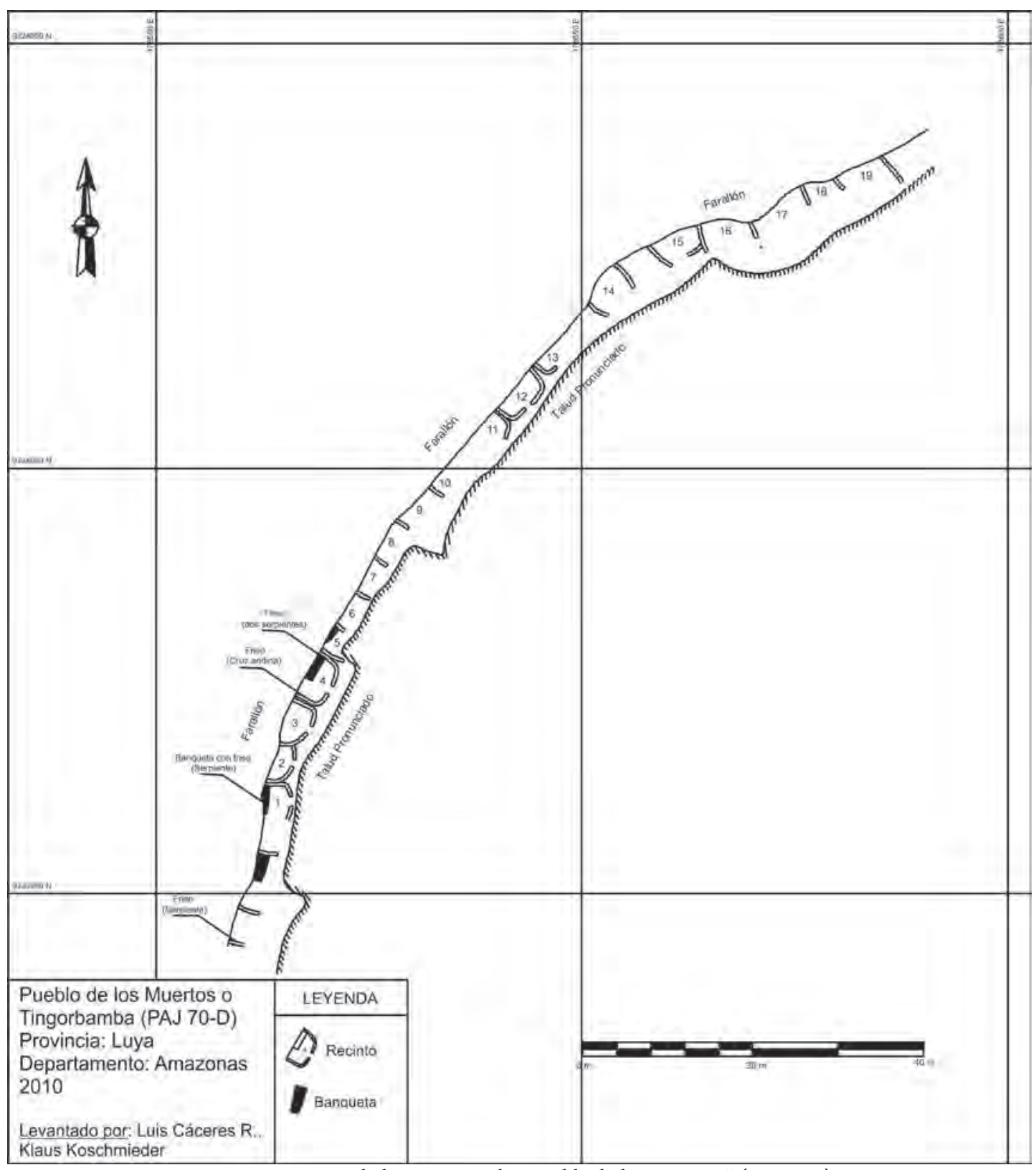

Figura 26. Mapa de la parte sur de "Pueblo de los Muertos" (PAJ 70-D). 


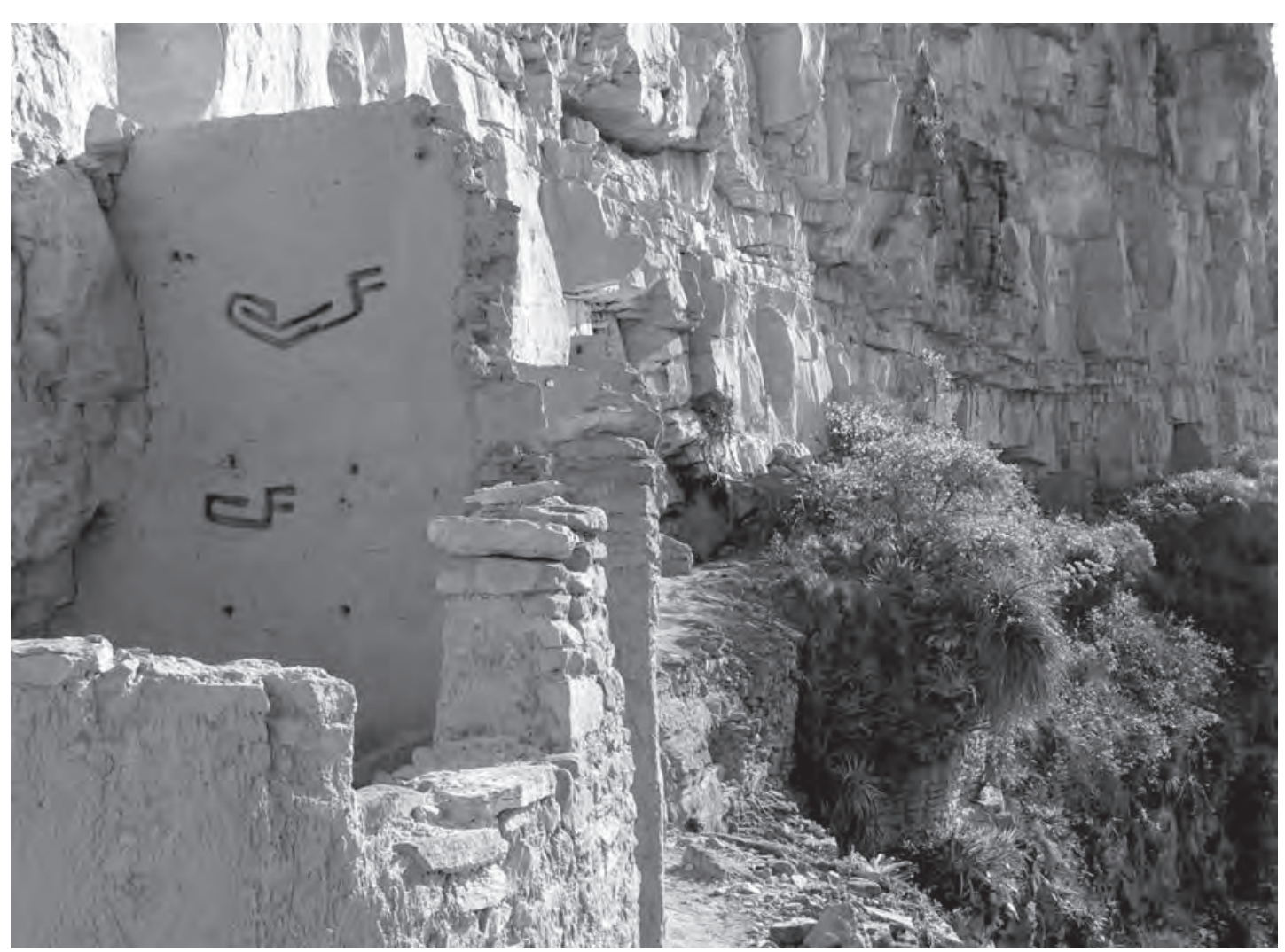

Figura 27. Frisos en bajorrelieve en el edificio 4 ("Pueblo de los Muertos" - PAJ 70-D).

encorvado. Estos frisos tienen un largo de 0,60-0,90 m y una altura de 0,25-0,40 m. Una serpiente de forma más natural decoró la pared exterior de una banqueta con nichos (edificio 1) (Kauffmann/Ligabue 2003: 330; Koschmieder 2012: 123). Presenta su cuerpo serpentiforme de $1 \mathrm{~m}$ de largo y su cabeza, originalmente dotada de un ojo. ${ }^{42}$ Según los estudios iconográficos, las serpientes fueron consideradas como representantes de las autoridades máximas (Lerche 1995). El motivo cruciforme (edificio 4) de «Pueblo de los Muertos» fue elaborado con las técnicas de la incisión y excisión (Koschmieder 2012: 141). La chakana o "cruz andina» es un símbolo milenario de los pueblos andinos, interpretado como «eje ordenador de la cosmovisión andina» (Estermann 2008; Lozano 1990).

En el espacio interior de los recintos de «Pueblo de los Muertos» se identificaron algunas banquetas (naturales y artificiales) con un alto de $0,4 \mathrm{~m}$, batanes, morteros, manos de moler y fogones. Algunos de los batanes muestran concavidades, mientras las manos de moler están dotadas de protuberancias redondas que servían para manejar las manzuelas con más facilidad. Encima de los pisos, generalmente limpios, se registraron algunos restos vegetales (maíz).

Al parecer los edificios semicirculares de «Pueblo de los Muertos» sivieron para fines domésticos. Es de suponer que fueron frecuentados durante ciertos eventos funerarios que se desarrollaron en los otros sectores con sarcófagos (A-C, E). Los recintos deben haber servido como viviendas temporales y lugares para la preparación de los convites mortuarios. No sirvieron como «mausoleos» o "graneros» (Kauffmann 2009: 170; Kauffmann/Ligabue 2003: 329), pues no hay indicios (p.ej. entierros) que podrian comprobar estas hipótesis.

42 A causa de los daños, provocados por los visitantes, la cabeza de la serpiente ya no está visible. 


\section{CORRALPAMPA (PAJ 36)}

El sitio arqueológico Corralpampa (PAJ 36) se ubica en la margen izquierda del río Utcubamba a una altura de 2346-2364 msnm (Fig. 3). Consta de cinco sectores (A-E), los cuales se distribuyen en diferentes alturas. En todos los sectores se ubican edificios semicirculares, algunos asociados a pinturas rupestres. Las estructuras fueron levantadas sobre terrazas artificiales y muestran un ancho máximo de 3,4-6,2 m. Los accesos se ubican en el lado noreste (hacia el valle) y tienen un ancho de 0,6-0,8 m. Los muros, algunos con cimientos compuestos de grandes rocas (sector B), mantienen su altura original de 3,0-3,4 m. En la cima muestran vanos de luz («ventanas»), mientras en el paramento interior se observan ganchos de madera (huacalas) en forma de «V».

Se limpió el espacio interior de uno de los edificios en el sector B (Fig. 28). Un batán de forma irregular se ubicó encima de una banqueta natural (oeste). Tiene un alto de 0,23-0,30 m y una superficie casi plana. El piso de barro, bién conservado en la parte sur del recinto, se ubica delante de la banqueta. Encima se hallaron fragmentos de morteros y manos de moler (manzuelas). Destacan los hallazgos de unos pinceles de fibra vegetal y los fragmentos de un cuenco de cerámica, el cuál contenía los restos de una pintura roja (hematita). Sirvió para pintar las rocas cercanas al edificio. Del piso se recuperaron también huesos de llamas y vizcachas, tusas de maíz, pepas de lúcuma y fragmentos de mate (Koschmieder 2012: 91, 94).

Cerca al muro norte se registró una rotura en el piso. Durante las excavaciones se documentaron tres entierros en el relleno debajo del piso (Koschmieder 2012: 66), los cuales fueron depositados después del abandono del edificio, ya que el piso no fue renovado después del entierro. Los restos óseos pertenecían a dos adultos de 40 a 50 años (hombre/mujer) y a un subadulto (niño) de 1 a 2 años

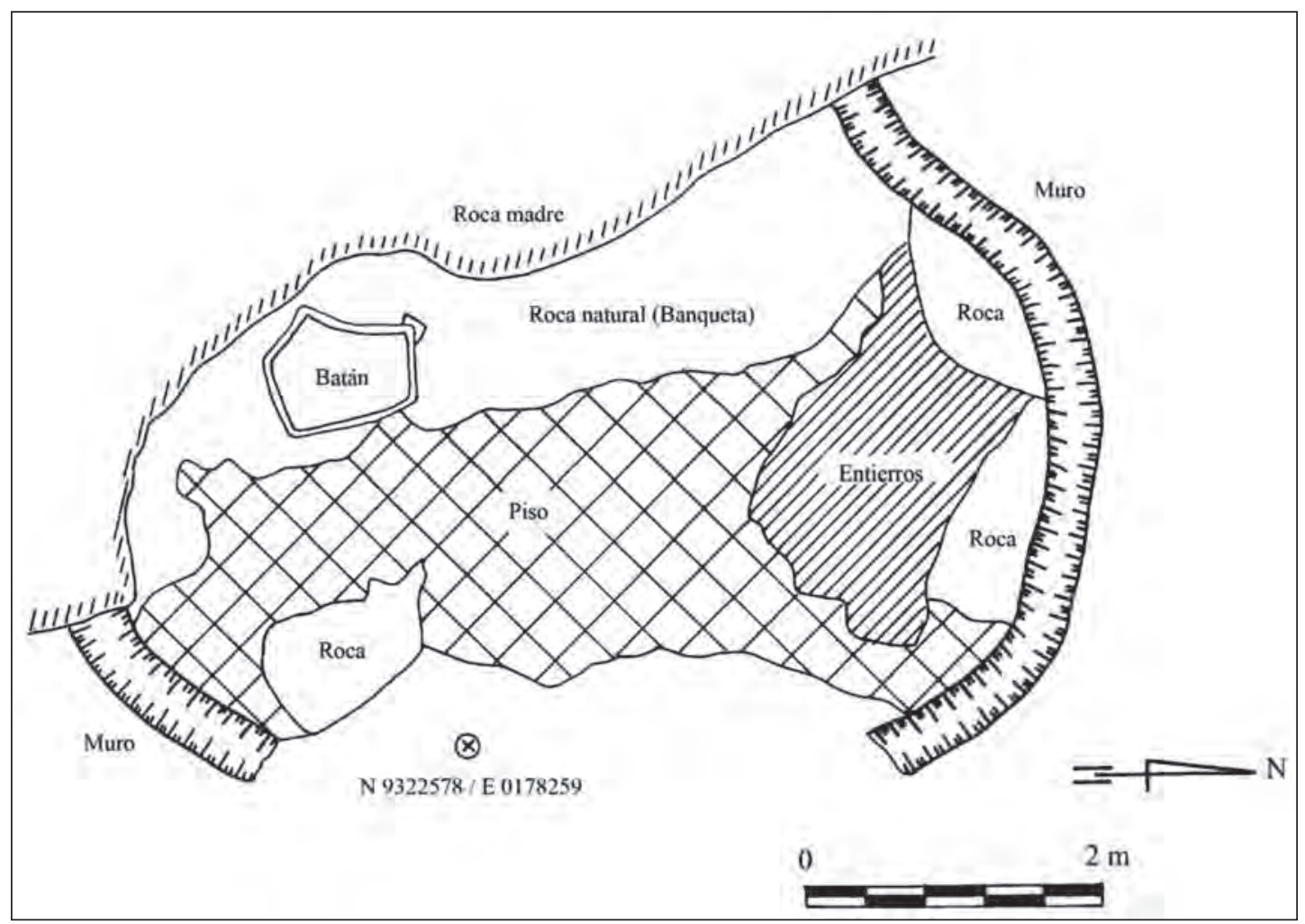

Figura 28. Espacio interior de uno de los edificios semicirculares de Corralpampa (PAJ 36-B). 
de edad. La estatura de los adultos fue de $148 \mathrm{~cm}$ (mujer) y $162 \mathrm{~cm}$ (hombre). Solamente el esqueleto de la mujer se halló en forma completa, enterrado en una posición fetal. Se registraron fracturas y un orificio de trepanación $(23$ x $19 \mathrm{~cm})$ en el cráneo. Entre las pocas ofrendas figuran un falange de camélido perforada y varios proyectiles para hondas.

Pensamos que los tres personajes han sido habitantes del edificio y es posible que murieran durante un asalto, ya que muestran fracturas y fueron enterrados simultáneamente. Después de este incidente el edificio fue desocupado. En primer lugar consideramos los edificios semicirculares como viviendas. Sitios como Corralpampa (PAJ 36), Amtia (PAJ 274) o Pucatambo (PAJ 97) se encuentran en lugares de dificil acceso y son casi invisibles. Probablemente se trata de refugios durante los conflictos entre los diferentes grupos chachapoya.

\section{CARNEROCUNGA (PAJ 158)}

El sitio de Carnerocunga (PAJ 158) se ubica al lado sur del Cerro Mito en la base de un acantilado de difícil acceso. Se encuentra a una altura de $1937 \mathrm{msnm}$ (Fig. 3). El sitio consta de cuatro estructuras, las cuales fueron construidas sobre una estrecha repisa geológica (ancho: 4,5-6,5 m) y debajo de unas rocas sobresalientes (Fig. 29). En la parte sur del sitio un muro de contención delimita el área de los dos recintos mejor conservados. Tienen una forma circular (edificio 1) o semicircular (edificio 2). Los muros mantienen una altura de 2,3-2,6 $\mathrm{m}$ y un ancho de 0,20-0,25 m. En el paramento interior de los recintos se observan huesos y maderos incrustados así como orifícios que sirvieron para poner las vigas de un techo horizontal. Las estructuras tienen un diámetro máximo de 3,6 (edificio 1) y 5,0 m (edificio 2). Las excavaciones arqueológicas se realizaron en el espacio interior de los dos recintos. Adicionalmente se excavó un cateo $\left(1,5 \mathrm{~m}^{2}\right)$ entre los dos edificios, donde se hallaron restos óseos humanos en la superficie.

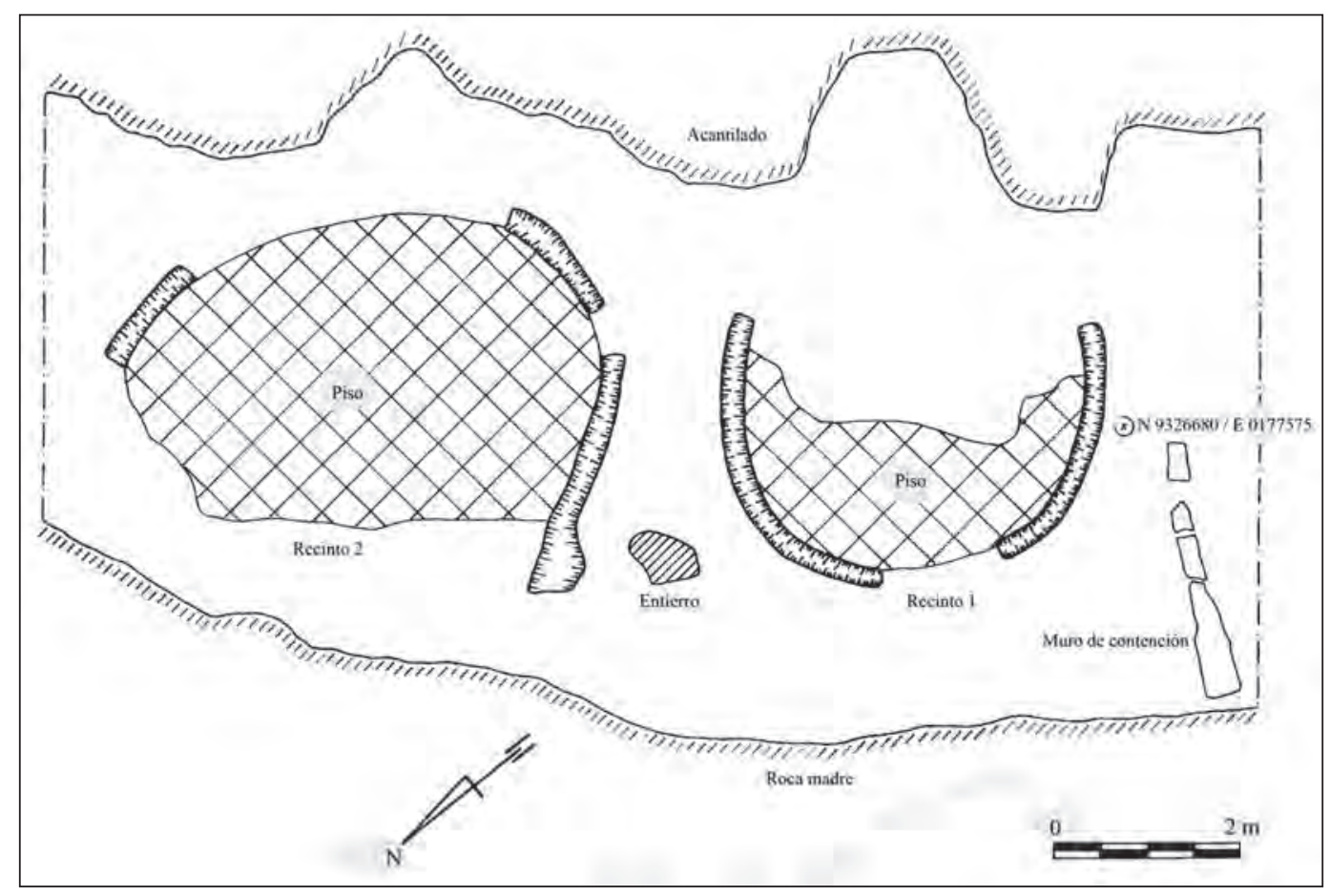

Figura 29. Mapa del sitio arqueológico Carnerocunga (PAJ 158) 
En el interior de cada uno de los edificios se registró una superposición de cuatro pisos de barro. Encima de los pisos se hallaron granos y tusas de maíz. Probablemente se trata de antiguos «graneros», construidos en un sitio seco y bién ventilado. ${ }^{43}$

En el cateo (Fig. 29) se halló el esqueleto de una joven mujer, envuelto en textiles, que murió a una edad de 15 a 20 años. El esqueleto se encontró en una posición decúbito lateral y estuvo parcialmente momificado. Como se halló cerca a la superficie actual, faltó el cráneo, mientras otros huesos fueron roidos por animales. Es de suponer que la joven mujer tuvo la tarea de cuidar a los graneros, pero no tenemos indicios en que forma murió. No se encontraron ofrendas especiales, solamente huesos trabajados y una hacha de piedra fragmentada.

\section{RESUMEN}

En su gran mayoría los edificios semicirculares deben haber servido como viviendas, algunos temporales, ya que la presencia de banquetas, batanes, morteros, manos de moler, fogones y desechos orgánicos sugiere una función doméstica. Por razones de seguridad los asentamientos fueron establecidos en lugares estratégicos y de difícil acceso. Los recintos se encuentran en mal estado de conservación, ya que los muros sufrían de la caida de las rocas durante los fuertes sismos. No fueron mausoleos, pero asentamientos como Pueblo de los Muertos están asociados con sitios funerarios cercanos. En el área de investigación se registró un solo sitio con graneros (Carnerocunga), los cuales fueron construidos en un lugar fresco y seco. Al parecer sirvieron para almacenar mazorcas de maíz.

\section{EL ROL DE KUELAP EN EL NORTE DEL TERRITORIO CHACHAPOYA}

Kuelap fue el sitio más imponente en el territorio norte de los chachapoya. La «ciudad fortificada» se ubica sobre una cresta rocosa a una altura de $3000 \mathrm{msnm}$ y cubre un área de aproximadamente 6 hectáreas (Narváez 1988: 116). El muro perimétrico, que define el contorno del sitio arqueológico, tiene una altura de hasta $20 \mathrm{~m}$ y fue construido con grandes bloques de calizas. De lejos parece como uno de los muchos acantilados naturales, donde se ubican los sitios funerarios por excelencia. Y de hecho se registraron numerosos entierros (secundarios) en el interior del muro perimétrico (Langlois 1934: 30; Narváez 1988: 118). Al parecer los constructores de Kuelap tenían la intención de levantar su asentamiento sobre un «cerro artificial». Por las entradas principales se llega a unos callejones amurallados que culminan en un estrecho pasaje que permite el paso de una sola persona, así que el acceso hacia el interior de la «ciudad fortificada» ha sido estrictamente controlado. Pero no se trata de una fortaleza en toda la extensión de la palabra, ya que faltan parapetos y algunas de las estructuras circulares fueron construidas al borde del muro perimétrico. Por esta razón surge la pregunta sobre la función principal de esta construcción monumental.

En el interior de la «fortaleza» y encima de las dos plataformas artificiales (Pueblo Bajo y Pueblo Alto) se ubican 420 estructuras circulares y cinco edificios de forma rectangular. Se observan algunas particularidades en la organización del espacio interior de los edificios circulares. En vez de los peldaños semicirculares, típicos para los sitios al norte de Kuelap, se observan escalones que descienden hacia el interior de los recintos. Una estructura típica muestra una banqueta en la parte trasera del espacio interior, batanes, manos de moler y una o más cámaras subterráneas, empotradas en el piso (Fig. 30) (Narváez 1996 b: 96).

Especialmente las cámaras subterráneas, revestidas con piedras, están ausentes en el área de Lámud-Luya. Son consideradas como almacenes para guardar las semillas y/o cosechas y se encuentran solamente en sitios encima de los 3000 msnm (p.ej. Guengerich 2012; Muscutt et al. 1993; Schje-

43 «Graneros« similares fueron visitados por el equipo de Kauffmann-Doig en Wanglic, vallle del rio Tincas, pero los investigadores no excavaron en este sitio (Kauffmann/Ligabue 2003: 334-336). 


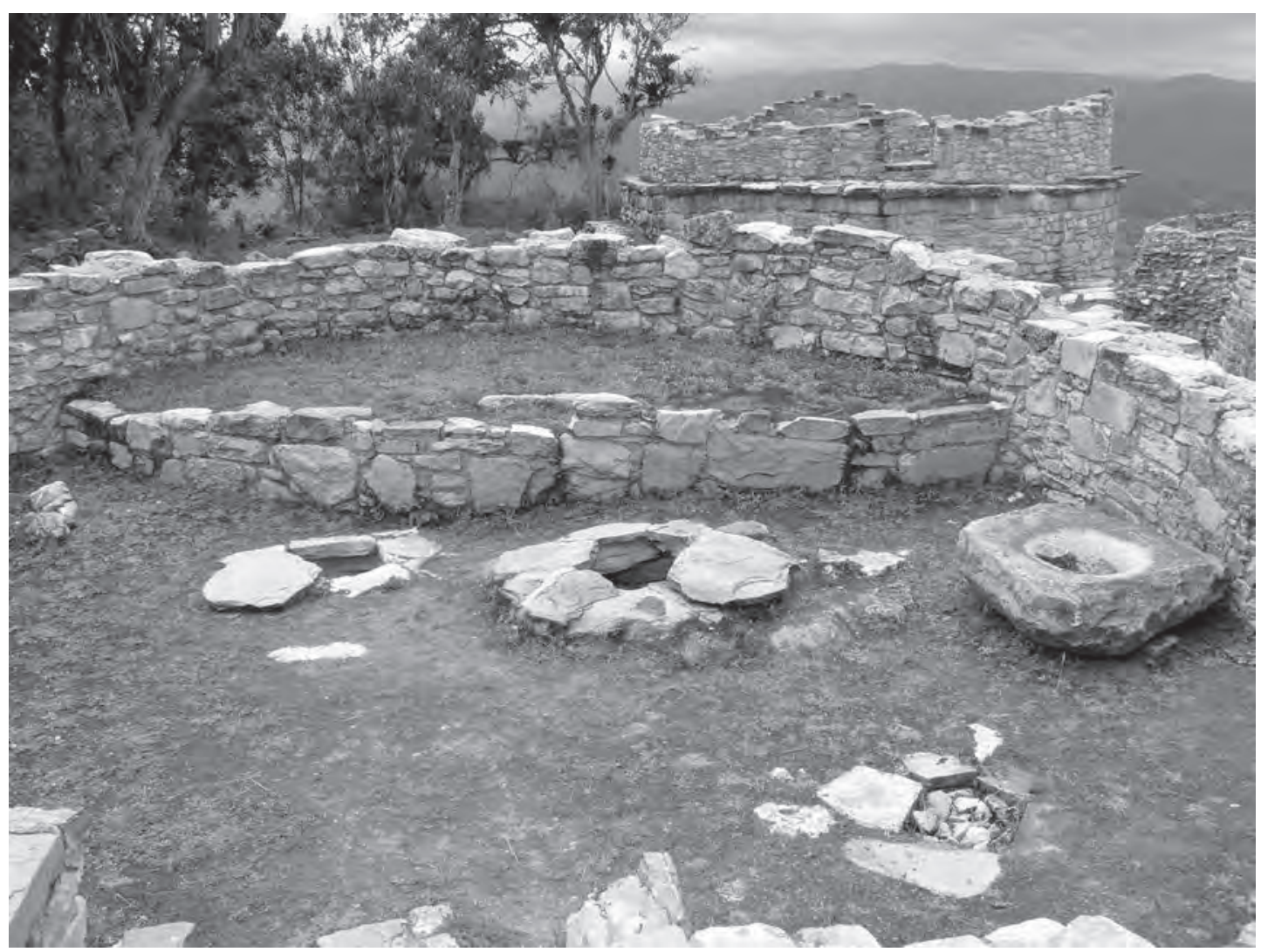

Figura 30. Interior de uno de los edificios circulares de Kuelap (con banqueta, batán y cámaras subterráneas).

llerup 2005; Thompson 1974, 1976). La presencia de las cámaras subterráneas podria explicar en parte la función de Kuelap, ya que el sitio se encuentra encima de uno de los pocos cerros de la región que alcanza una altura de $3000 \mathrm{msnm}$, mientras en el territorio alrededor del Kuelap, especialmente en la zona de Lámud-Luya, los asentamientos se ubican en alturas entre 2450 y 2700 msnm y carecen de las cámaras subterráneas. Las temperaturas a estas alturas no son suficiente bajas para facilitar el almacenamiento de los productos vegetales. En combinación con la extrema humedad pueden causar problemas con hongos y parásitos. Sobre todo para almacenar la papa se necesita un ambiente frio que evita la germinación del tubérculo (Lerche 1986, 1996).

Al parecer los diferentes grupos étnicos del territorio norte se aliaron para buscar una solución como enfrentar el problema más grave, que fue la falta de víveres en tiempos de crisis. Previamente en tiempos de crisis hubo conflictos bélicos entre los diferentes grupos chachapoya por los pocos recursos restantes. Con la construcción de Kuelap crearon un lugar donde los productos básicos fueron administrados, protegidos y redistribuidos. Al parecer, los accesos estrechos de Kuelap sirvieron para controlar la llegada y la salida de los productos vitales. Es de suponer que despúes de ciertas catástrofes naturales, como por ejemplo una sequía severa, los administradores de Kuelap distribuyeron los alimentos básicos y defendieron el lugar durante la incursión de grupos hostiles, acostumbrados a asaltar para asegurar su subsistencia.

Los edificios circulares de Kuelap sirvieron en primer lugar como viviendas y unidades administrativas. En las cámaras subterráneas se almacenaron los productos agrícolas hasta el momento de su distribución a los necesitados. Los recintos circulares per se no fueron «graneros» como postulaba 
Kauffmann (Kauffmann/Ligabue 2003: 128, 130, 140-141). Los resultados de las excavaciones arqueológicas, dirigidas durante los últimos años por el arqueólogo Alfredo Narváez, comprueban su función doméstica (y administrativa). Regularmente se enterraron también gente en el interior de los edificios, probablemente algunos de sus habitantes. Kuelap no solamente fue un centro administrativo, sino cumplía también una función ceremonial. El «Tintero» fue el edificio ceremonial por excelencia (Narváez 1988), ya que se encontraron evidencias de entierros y ofrendas en su interior. También podria haber servido como un observatorio astronómico (McGraw et al. 1996).

\section{CONCLUSIONES}

El arqueólogo F. Kauffmann-Doig postula que los edificios circulares de piedra, típicos para la arquitectura chachapoya, fueron "graneros» y que la mayoría de las poblaciones chachapoya vivían en estructuras rústicas de adobe o tapial, las cuales (según su opinión) llevaban techos de dos aguas, similares a los de los mausoleos de Revash (Kauffmann 2009: 62-65, 71-72, 163; Kauffmann/Ligabue 2003: 127-130, 141). Las hipótesis de Kauffmann no tienen fundamento, ya que no excavó en sitios chachapoya y no toma en cuenta los resultados de las excavaciones arqueológicas en Kuelap (Narváez 1988; 1996 a y b) y en los demás asentamientos residenciales. Las investigaciones recientes demuestran que los edificios circulares sirvieron como viviendas, pero también para fines administrativos (cámaras subterráneas) y ceremoniales (p.e. el «Tintero» o los recintos grandes de Kacta). Restos de estructuras de quincha, identificados por primera vez en la zona de Lámud-Luya, pertenecían a grupos nativos que vivían en épocas anteriores a la llegada de los chachapoya (Koschmieder 2012: 36).

En el área de investigación, entre los rios Jucusbamba y Utcubamba (Fig. 3), los asentamientos residenciales chachapoya se ubican en su gran mayoría en las cumbres de las montañas. No muestran patios públicos y tampoco edificios de carácter ceremonial o administrativo. Las estructuras circulares sirvieron básicamente como viviendas y/o talleres para una producción artesanal. En el espacio interior de los recintos se hallaron batanes, manos de moler, morteros y deshechos orgánicos. No muestran las típicas banquetas y las cámaras subterráneas (almacenes), identificadas en Kuelap, pero se documentaron otros rasgos importantes, como un reservorio de agua y un canal de desagüe (Chichita). La ausencia de las cámaras subterráneas o almacenes se explica con las condiciones climáticas desfavorables (altas temperaturas) a estas alturas (aprox. 2450-2650 msnm). No permitían el almacenaje de los productos agrícolas. Solamente sitios encima de los $3000 \mathrm{msnm}$ están dotados de cámaras subterráneas, así que en el territorio sur casi todos los asentamientos tenían sus propias cámaras de almacenaje. Por otro, lado en el territorio norte la administración de los productos agrícolas fue centralizada en Kuelap, el único sitio monumental que se ubica encima de los 3000 msnm.

En la zona de investigación los asentamientos que se ubican en las laderas de los cerros fueron habitados temporalmente. En su gran mayoría se hallan cerca de los campos de cultivo (p.ej. Pullía). Parece que fueron frecuentados exclusivamente durante los períodos de la siembra y cosecha. Los edificios son pequeños y simples y no muestran rasgos arquitectónicos especiales. En el espacio interior de los edificios no se encontraron desechos orgánicos, tampoco batanes, manos de moler o fogones.

El único asentamiento de carácter ceremonial ha sido Kacta. Al parecer, en sus edificios de gran tamaño se realizaron ciertas ceremonias, relacionadas a unos eventos funerarios. Una pintura mural con la escena de una danza o de un ritual, y la presencia de entierros en uno de los «lugares públicos», confirman esta hipótesis. Por otra parte los edificios menores sirvieron como cocinas y viviendas temporales durante las festividades. Algunos se encontraron vacíos y en forma limpia, otros presentan batanes, manos de moler, fogones y deshechos orgánicos.

Novedosos son los estudios de asentamientos con edificios semicirculares que se ubican en la base de los acantilados, probablemente por razones estratégicas. Los recintos, adosados a la roca natural, sirvieron en primer lugar como viviendas (temporales). En los espacios interiores se regis- 
traron banquetas, depósitos, batanes, manos de moler y desechos orgánicos. Sitios como «Pueblo de los Muertos» están asociados con sarcófagos y/o chullpas y fueron frecuentados solamente durante los eventos funerarios que se desarrollaron en estos lugares. Sus edificios no sirvieron como «mausoleos» o "graneros» como postulaba Kauffmann (Kauffmann 2009: 170; Kauffmann/Ligabue 2003: 329), sino como viviendas temporales y lugares para la preparación de la comida funeral. Los únicos «graneros» identificados en el área de investigación se ubican en Carnerocunga, pero les consideramos como «almacenes temporales» donde se guardaban las cosechas hasta su transporte hacia otros lugares en las alturas.

\section{Agradecimientos}

Agradecemos al Ex-Instituto Nacional de Cultura de Lima (hoy: Ministerio de Cultura) por haber aprobado el «Proyecto Arqueológico Chichita» (Resolución Directoral Nacional N 1744 del 18 de octubre del 2006) y el «Proyecto Arqueológico Jucusbamba» - Temporadas 2007 y 2009 (Resolución Directoral Nacional N 558 del 3 de mayo del 2007 y Resolución Directoral Nacional N 1494 del 24 de octubre del 2008). También a la entidad financiera de los dos proyectos de investigación arqueológica, la «Deutsche Forschungsgemeinschaft» (Comunidad Alemana de Investigaciones). Amablemente la Dra. Sonia Guillén del Centro Mallqui proporcionó el mapa con la ubicación del territorio de la «cultura arqueológica Chachapoya» (Fig. 1).

Los trabajos de campo fueron dirigidos por el autor y los arqueólogos nacionales Mario Advíncula Z., Rolando Paredes G., Jeisen Navarro V. y Jaime Jiménez S. Expresamos toda nuestra gratitud a todos aquellos pobladores de Lámud y sus alrededores, quienes demostraron comprensión y facilitaron nuestra exploración. Además a los señores Juan Mestanza P., Orlando Poquis R., Juan Gupioc A., Javier Sinarahua S., Cleimer Fernández G., Alfonso Chavez H. y a la señorita Roxana Mori U. por ayudar en los trabajos de campo. Al igual agradecemos a los arqueólogos Andersson Sernaqué C. y Alex León C. (Universidad Nacional de Trujillo) por su participación en los trabajos de campo.

Los trabajos de topografía fueron dirigidos por el arqueólogo Luis Cáceres R. El material arqueológico fue analizado por Catherine Gaither y sus estudiantes (Óseo humano), Victor Vásquez S./Teresa Rosales T. (Óseo animal, restos vegetales y malacológico), Arabel Fernández L. (Textiles), Rodrigo Zuzunaga I. (Metales), Walter Vásquez S. (Geología) y Cesar Gálvez M. (Líticos). El Sr. Felix Farro B. (Museo de Sechín, Casma) se dedicó a elaborar los dibujos de la cerámica diagnóstica y de otros objetos. A todos ellos mi sincero agradecimiento. 


\section{BiBLIOGRAFÍA}

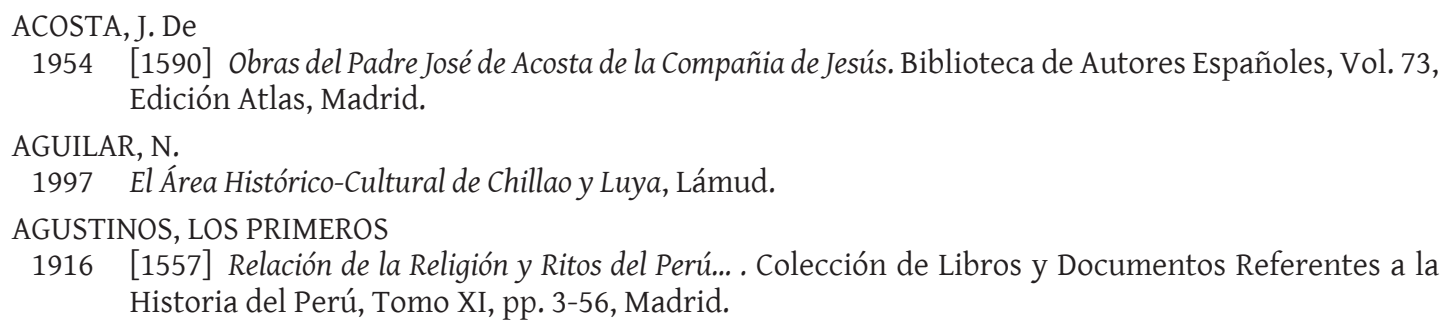

ARRIAGA, P. J.

1951 [1586] La Extirpación de la Idolatría del Pirú. Edición facsimilar (Ed. H. Urteaga), Tomo I, Serie 2, Lima.

BANDELIER, A.

1907 The Indians and Aboriginal Ruins Near Chachapoyas in Northern Peru. Historical Records and Studies, New York.

1940 «Los Indios y las Ruinas Aborigenes cerca de Chachapoyas en el Norte del Perú.» En: Chaski, Vol. 1, No. 2, pp. 13-59, Lima.

BONAVÍA, D.

1968 Las Ruinas del Abiseo. Universidad Peruana de Ciencias y Tecnología, Lima.

1998 «La Colonización Incaíca de la Selva Alta.» En: Arkinka 34, pp. 88-96, Lima.

BUENO, A., M. Cornejo y G. Savoy

2006 «Prospecciones y Excavaciones Arqueológicas en la Cuenca del Río Guabayacu, Región San Martin.» En: Cantuta (Revista Institucional de la UNE), No. 16, pp. 57-74, Lima.

CALANCHA, A. de

1976 [1638] Corónica Moralizada del Orden de San Agustin. Prador Pastor, Lima.

CHURCH, W.

1994 «Early Occupation at Gran Pajatén, Perú.» En: Andean Past, No. 4, pp. 281-318, Ithaca.

CHURCH, W. y A. v. HAGEN

2008 «Chachapoyas: Cultural Development at an Andean Cloud Forest Crossroads.» En: Handbook of South American Archaeology, H. Silverman y W. Isbell (eds.), Cap. 45, pp. 903-926, Springer, New York.

CIEZA DE LEÓN, P.

1984 [1553] Crónica del Perú. Primera Parte, PUCP, Lima.

1987 [1553] Crónica del Perú. Tercera Parte, PUCP, Lima.

DAVIS, M.

1985 Chachapoyas. The Cloud People. An Antropological Survey. Ontario.

1996 La Casa Redonda and Yurac-Urco: Two Round Houses in Department Amazonas, Perú. Noelville, Ontario.

ESPINOZA S., W.

1967 «Los Señorios Étnicos de Chachapoyas y la Alianza Hispano-Chacha.« En: Revista Histórica 30, pp. 224-333, Lima.

ESTERMANN, J.

2008 Si el Sur Fuera el Norte - Chakanas Interculturales Entre Andes y Occidente. Ediciones Abya-Yala, Quito.

GAITHER, C.

2007 Informe Osteológico. Proyecto Arqueológico Chichita.

GAITHER, C., K. KOSCHMIEDER y G. LOMBARDI

2008 «En la Tierra de los Gigantes: Un Nuevo «Gigante» Encontrado en el Sitio Nor-Andino de Chichita, Perú.» En: Arqueobios, Vol. 2, pp. 28-39, Trujillo.

GARCILASO DE LA VEGA, Inca

1965 [1609] Obras Completas. Biblioteca de Autores Españoles, Vol. II, Ediciones Atlas, Madrid. 


\section{GIFFHORN, H}

2013 Wurde Amerika in der Antike Entdeckt? Karthager, Kelten und das Rätsel der Chachapoya. Verlag C.H. Beck, München.

GIL, N.

1938 «Dos Pueblos Prehistóricos Kuelapenses - Kacta y Chipuric.» En: Boletin de la Sociedad Geográfica de Lima 55, pp. 132-139, Lima.

GUENGERICH, A.

2012 Proyecto Arqueológico Pueblo Chachapoya (PAPCHA). Sitio de Monte Viudo, Chachapoyas, Amazonas. Informe Final presentado al Ministerio de Cultura, Lima.

HAGEN, A.v.

2002 «Pueblo de las Nubes.« En: Chachapoyas - El Reino Perdido, pp. 25-261, Integra/AFP, Lima.

HORKHEIMER, $\mathrm{H}$.

1958 «Algunas Consideraciones Acerca de la Arqueología en el Valle del Utcubamba.» En: II. Congreso Nacional de Historia del Perú/Época Prehispánica 1, pp. 71-90 + Láminas IX-XIX, Lima.

KAUFFMANN DOIG, F.

1989 «Andes Amazónicos: Sitios Intervenidos por la Expedición Antisuyo/86.» En: Arqueológicas (Museo Nacional de Antropología y Arqueología) 20, pp. 5-57 + 19 planos, Lima.

2009 Constructores de Kuélap y Pajatén - Los Chachapoyas. Centro de Investigaciones Turismo Kuelap S.A., Lima.

KAUFFMANN DOIG, F. y. G. LIGABUE

2003 Los Chachapoya(s) - Moradores Ancestrales de los Andes Amazónicos Peruanos. Universidad Alas Peruanas, Lima.

KOSCHMIEDER, $\mathrm{K}$.

2008 Proyecto Arqueológico Jucusbamba. Informe presentado al Instituo Nacional de Cultura, Lima.

2012 Jucusbamba - Investigaciones Arqueológicas y Motivos Chachapoya en el Norte de la Provincia de Luya, Departamento Amazonas, Perú. Tarea Asociación Gráfica Educativa, Lima.

KOSCHMIEDER, K. y C. GAITHER

2010 «Tumbas de Guerreros Chachapoya en Abrigos Rocosos de la Provincia de Luya, Departamento Amazonas.» En: Arqueología y Sociedad 22, pp. 9-37, UNMSM, Lima.

KOSCHMIEDER, K. y R. PAREDES

2007 Proyecto Arqueológico Chichita. Informe presentado al Instituto Nacional de Cultura, Lima.

LANGLOIS, L.

1934 «Conferencia - Las Ruinas de Cuelap.» En: Boletin de la Sociedad Geográfica de Lima 51 (1), pp.20-34, Lima.

1939 Utcubamba. Imprenta del Museo Nacional, Lima.

LERCHE, P.

1986 Häuptlingstum La Jalca - Bevölkerung und Ressourcen bei den Vorspanischen Chachapoya, Perú. Dietrich Reimer Verlag, Berlin.

1995 Los Chachapoya y los Símbolos de su Historia. Servicios Editoriales César Gayoso, Lima.

1996 Chachapoyas - Guia de Viajeros. Intigráfica - César Gayoso Servicios Editoriales, Lima.

LENNON, T., W. CHURCH y M. CORNEJO

1989 «Investigaciones Arqueológicas en el Parque Nacional Rio Abiseo, San Martin.» En: Boletin de Lima 62, pp. 43-56, Lima.

LOZANO, A.

1990 Cusco - Cosqo - Modelo Simbólico de la Cosmología Andina. Cusco.

MCGRAW, J., M. ONCINA, D. SHARON y C. TORRES

1996 Kuelap: A Solar Observatory? San Diego Museum of Man, Ethnic Technology Notes 24, San Diego.

1974 [1895] Perú. Tomo III (La Sierra), UNMSM, Lima. 
MURÚA, Fray M. de

2001 [1611] Historia General del Perú. Ed. M. Ballesteros Gaibrois, Crónicas de América.

MUSCUTT, K.

1998 Warriors of the Clouds - A Lost Civilization in the Upper Amazon of Perú. Albuquerque.

MUSCUTT, K., V. LEE y D. SHARON

1993 Vira Vira: A «New» Chachapoya Site. Sixpacmanco Publications, Wilson.

NARVÁEZ, A.

1988 «Kuélap: Una Ciudad Fortificada en los Andes Nororientales de Amazonas, Perú.« En: Arquitectura y Arqueología (CONCYTEC), pp. 115-142, Chiclayo.

1996a «La Fortaleza de Kuelap.» En: Arkinka - Revista de Arquitectura, Diseño y Construcción, No. 12, pp. 92-109, Lima.

1996b «La Fortaleza de Kuelap.» En: Arkinka - Revista de Arquitectura, Diseño y Construcción, No. 13, pp. 90-98 (Segunda Parte), Lima.

PIZARRO, P.

1986 [1557] Relación del Descubrimiento y Conquista de los Reinos del Perú. PUCP, Lima.

POLO DE ONDEGARDO, J.

1916 [1567] Instrucción Contra las Ceremonias y Ritos que Usan los Indios Conforme al Tiempo de su Infidelidad. Colección de Libros y Documentos Referentes a la Historia del Perú, Serie I, Tomo III, pp. 189-203, Lima.

RAVINES, R.

1994 «Los Grupos Étnicos Cisandinos.» En: Historia General del Perú - Las Culturas Preincaicas, Tomo II, pp. 506-526 (Grupos Étnicos del Marañon), Editorial Brasa S.A., Lima.

REICHLEN, H. u. P. REICHLEN

1950 «Recherches Arqueológiques Dans les Andes de Haut Utcubamba.« En: Journal de la Societé des Americanistes 39, pp. 219-246, Paris.

RUIZ ESTRADA, A.

2009 [1972] La Alfarería de Cuélap: Tradición y Cambio. Avqi Ediciones, Lima.

2010 Amazonas: Arqueología e Historia. Universidad Alas Peruanas, Lima.

SALINAS LOYOLA, J. de

1965 [1571] «Cartas» En: Relaciones Geográficas de las Indias, Vol. III, p. 197, Madrid.

SAVOY, G.

1970 Antisuyo - The Search of the Lost Cities of the Amazon, New York.

1996 The Gran Vilaya Expeditions: Reclaiming a Vast Urban Center from the Upper Montane Forest of Amazonas, Perú.

SCHJELLERUP, I.

2005 Incas y Españoles en la Conquista de los Chachapoya. PUCP y IFEA, Lima.

SCHJELLERUP, I., C. ESPINOZA, J. ROLLEFSON, V. QUIPUSCOA, M. KAMP y V. PEÑA

2008 La Ceja de Montaña - Un Paisaje que va Desapareciendo. The National Museum of Denmark, Ethnographic Monographs, No. 3.

SCHJELLERUP, I., M. KAMP, C. ESPINOZA, V. QUISPUSCOA y V. PEÑA

2003 Los Valles Olvidados - Pasado y Presente en la Utilización de Recursos en la Ceja de Selva, Perú. The National Museum of Denmark, Ethnographic Monographs, No. 1.

SCHJELLERUP, I., V. QUISPUSCOA, C. ESPINOZA, V. PEÑA y M. KAMP

2005 The Chilchos Valley Revisited - Life Conditions in the Ceja de Selva, Perú. The National Museum of Denmark, Ethnographic Monographs, No. 2.

THOMPSON, D.

1974 «Investigaciones Arqueológicas en los Andes Orientales del Norte del Perú.» En: Revista del Museo Nacional, Tomo XXXIX, pp. 117-125, Lima.

1976 «Prehistory of the Uchucmarca Valley in the North Highlands of Peru.» En: Actas del XLI. Congreso Internacional de Americanistas, Vol. II, México. 
VÁSQUEZ, W.

2006 Estudio Petrográfico Macroscópico - Sitio Arqueológico Chichita, Chachapoyas.

2008 Informe Técnico - Descripción y Clasificación Macroscópica de Líticos del Sitio Arqueológico Kacta, Chachapoyas.

WERTHEMANN, A.

1892 «Ruinas de la Fortaleza de Cuélap.» En: Boletin de la Sociedad Geográfica de Lima, Año 2, pp. 147-160, Lima.

WIENER, C.

1884 «Amazone et Cordilléres.» En: Le Tour du Monde, pp. 385-400, Paris.

ZUBIATE, V.

1984 Guia Arqueológica del Departamento de Amazonas, Chachapoyas. 